\title{
Bone Morphogenetic Proteins in Vascular Homeostasis and Disease
}

\author{
Marie-José Goumans, ${ }^{1}$ An Zwijsen, ${ }^{2,3}$ Peter ten Dijke, ${ }^{1,4}$ and Sabine Bailly ${ }^{5,6,7}$ \\ ${ }^{1}$ Department of Molecular Cell Biology, Leiden University Medical Center, 2300 RC Leiden, The Netherlands \\ ${ }^{2}$ VIB Center for the Biology of Disease, 3000 Leuven, Belgium \\ ${ }^{3} \mathrm{KU}$ Leuven Department of Human Genetics, 3000 Leuven, Belgium \\ ${ }^{4}$ Cancer Genomics Centre Netherlands, Leiden University Medical Center, 2300 RC Leiden, The Netherlands \\ ${ }^{5}$ Institut National de la Santé et de la Recherche Mécale (INSERM), U1036, 38000 Grenoble, France \\ ${ }^{6}$ Laboratoire Biologie du Cancer et de I'Infection, Commissariat à l'Énergie Atomique et aux Energies \\ Alternatives, Biosciences and Biotechnology Institute of Grenoble, 38000 Grenoble, France \\ ${ }^{7}$ University of Grenoble Alpes, 38000 Grenoble, France \\ Correspondence:m.j.t.h.goumans@lumc.nl; sabine.bailly@cea.fr
}

It is well established that control of vascular morphogenesis and homeostasis is regulated by vascular endothelial growth factor (VEGF), fibroblast growth factor (FGF), Delta-like 4 (DII4), angiopoietin, and ephrin signaling. It has become clear that signaling by bone morphogenetic proteins (BMPs), which have a long history of studies in bone and early heart development, are also essential for regulating vascular function. Indeed, mutations that cause deregulated BMP signaling are linked to two human vascular diseases, hereditary hemorrhagic telangiectasia and pulmonary arterial hypertension. These observations are corroborated by data obtained with vascular cells in cell culture and in mouse models. BMPs are required for normal endothelial cell differentiation and for venous/arterial and lymphatic specification. In adult life, BMP signaling orchestrates neo-angiogenesis as well as vascular inflammation, remodeling, and calcification responses to shear and oxidative stress. This review emphasizes the pivotal role of BMPs in the vascular system, based on studies of mouse models and human vascular disorders.

$\mathrm{B}_{\text {one morphogenetic proteins (BMPs) were }}$ originally discovered based on their capacity to induce bone and cartilage formation at ectopic sites (Urist 1965). As their pleiotropic functions have become apparent, it has been proposed to call them body morphogenetic proteins (Reddi 2005). BMPs comprise a dozen of the 33 known polypeptides of the transform- ing growth factor- $\beta$ (TGF- $\beta$ ) family (Bragdon et al. 2011; Katagiri and Watabe 2016). Most BMPs have been reported to elicit some effects on vascular cells. Based on their sequence similarity, receptor affinities and function, the BMP ligand polypeptides are classified into several subgroups including the BMP-2 and -4 group; BMP-5, -6, -7, $-8 \mathrm{a},-8 \mathrm{~b}$ group; BMP-9, -10

Editors: Rik Derynck and Kohei Miyazono

Additional Perspectives on The Biology of the TGF- $\beta$ Family available at www.cshperspectives.org

Copyright (C) 2018 Cold Spring Harbor Laboratory Press; all rights reserved; doi: 10.1101/cshperspect.a031989

Cite this article as Cold Spring Harb Perspect Biol 2018;10:a031989 
M.-J. Goumans et al.

group; and BMP-3, -3b, -11, -12, -13, -14, -15, and -16 group (Katagiri and Watabe 2016; Morikawa et al. 2016). Among the different BMPs, BMP-2, BMP-4, BMP-6, and BMP-7 have been shown to function in vascular biology. Additionally, BMP-9 and -10 have emerged as crucial factors in endothelial function and vascular diseases (David et al. 2009).

Several reviews discuss the emerging role of BMPs in vascular remodeling, focusing on vascular biology (Garcia de Vinuesa et al. 2016; Morrell et al. 2016) and their molecular targets (Luo et al. 2015). Here, we will describe human vascular disorders and animal models that have contributed to our understanding of the role of BMP signaling in cardiovascular diseases and that may help us to find more effective treatment modalities. A review on TGF- $\beta$ signaling in control of cardiovascular function has also been published (Goumans and ten Dijke 2017).

\section{VASCULAR DEVELOPMENT IN A NUTSHELL}

The vascular system circulates blood and lymph throughout the body and is critical for tissue growth, homeostasis and repair. Blood vessels supply tissues with oxygen and nutrients, whereas lymphatic vessels absorb and filter interstitial fluids from these tissues. Blood vessels comprise endothelial cells (ECs) and mural cells, such as vascular smooth muscle cells (VSMCs) and pericytes. Interactions and interplay between ECs and mural cells play pivotal roles in vascular biology (Risau 1997; Carmeliet and Jain 2011).

Vessel formation during embryonic development begins with vasculogenesis (i.e., the de novo formation of blood vessels from locally differentiating ECs). This is followed by angiogenesis, which entails remodeling of the honeycomb-like pattern of the primary plexus into a stable branched network of vessels. The vasculature further expands through sprouting angiogenesis (i.e., formation of new blood vessels from pre-existing ones) and vascular pruning (Eilken and Adams 2010; Korn and Augustin 2015). Capillary sprouting requires interactions among three different EC subtypes-tip cells, stalk cells, and quiescent phalanx cells-that each perform highly specific functions (De Smet et al. 2009). ECs can transition between subtypes, which is termed EC plasticity. During the activation phase of angiogenesis, increased vascular permeability and basement membrane degradation allows EC migration and proliferation into the extracellular space. These new sprouts are spearheaded by the tip cell and elongated by proliferation of the trailing stalk cells. In the resolution phase of angiogenesis, EC migration and proliferation are stalled, the basement membrane is reconstituted, and vessel maturation is promoted. Lumen formation will occur via fusion of neighboring sprouts (Gebala et al. 2016). Next, mesenchymal cells are recruited and subsequently differentiate into pericytes or VSMCs, which are attached to the newly formed vessel (Eilken and Adams 2010; Korn and Augustin 2015). Although blood vessels predominantly remain quiescent throughout adult life, they retain the capacity to rapidly form new vasculature in response to injury or pathological conditions. During this process, transitions between the resolution phase and the activation phase of angiogenesis are determined by an intricately regulated balance between the inducers and the inhibitors of these phases.

Angiogenesis requires the coordinated integration of multiple signaling cascades, including the vascular endothelial growth factor (VEGF), fibroblast growth factor (FGF), Notch/Deltalike protein 4 (Dll4), angiopoietin, ephrin, TGF- $\beta$, and BMP pathways. The BMP pathway plays an important role in maintaining vascular homeostasis and affects several processes, including the endothelial responses to shear stress, hypoxia, and inflammation.

\section{BONE MORPHOGENETIC PROTEINS}

BMP ligands are synthesized as dimers of large proproteins that include an amino-terminal signal peptide, a long propeptide, and a carboxyterminal mature peptide that contains a cystine knot (Mueller and Nickel 2012). These BMP proproteins are proteolytically cleaved by proconvertases to generate the active dimeric form (Miyazono et al. 2010). Although BMP process- 
ing is predominantly intracellular, it might also occur at the plasma membrane or extracellularly (Yadin et al. 2016). Dimerization to generate the active ligand requires a covalent disulphide bridge at the seventh conserved cysteine within each monomer outside of the cystine knot structure formed by the six other cysteines. Active BMPs are homodimeric but some heterodimers (i.e., BMP-2/5, BMP-2/6, and BMP-2/7) are more potent than the corresponding homodimers in certain experimental settings (Sieber et al. 2009). Mature BMP dimers remain noncovalently associated with their cleaved prodomains. The fact that prodomains confer latency to TGF- $\beta$ (and some other family members) but not to the BMPs remains unresolved and is currently being investigated for certain BMPs, including BMP-10 (Sengle et al. 2011; Jiang et al. 2016b; Yadin et al. 2016). The prodomain of BMP-9 does not inhibit its biological activity and is rapidly released from the mature protein on binding to the receptors (Kienast et al. 2016). Posttranslational modifications, including Nand O-glycosylation, strongly influence BMP activity, because glycosylation is important for BMP secretion, prolongs a BMP's half-life, and modulates BMP receptor binding and function (Saremba et al. 2008).

Regulation of cell differentiation, proliferation, and apoptosis require appropriate ligand concentration and activity, as well as tight regulation of the local availability of BMPs (Umulis et al. 2009). Upon secretion, ligand binding to extracellular matrix proteins may induce a conformational change that prevents ligand access to the BMP receptors (Wohl et al. 2016). Some prodomains (e.g., of BMP-2, $-4,-7$, and -10 , and growth and differentiation factor [GDF- 5 ) form stable complexes with extracellular proteins (e.g., fibrillin-1 or collagen IV), thereby restricting their diffusion in the extracellular space (Sengle et al. 2008; Wang et al. 2008; Ramirez and Rifkin 2009). BMP-4, BMP-6, BMP-9, and BMP-10 are detected in the circulation, and can therefore affect tissues and organs at a distance, as well as the endothelial lining of the vessels, through luminal activation of BMP receptors (David et al. 2008; Souza et al. 2008; Herrera and Inman 2009; Bidart et al. 2012).
Awell-established mechanism for regulating the extracellular availability of BMPs involves a gradient of BMP antagonists that prevents BMP binding to receptors and BMP action (Chang 2016; Hinck et al. 2016). Multiple secreted proteins (e.g., noggin, chordin, cerberus, matrix Gla protein [MGP], and follistatin) can sequester BMP ligands and impair their interactions with receptor complexes. Other interacting proteins, such as cross-veinless 2, also known as BMP-binding EC precursor-derived regulator or BMPER, may exert more complex effects by either decreasing or increasing BMP signaling (Yao et al. 2012). BMPER was originally identified in a screen for proteins that are differentially expressed in embryonic endothelial precursor cells (Moser et al. 2003), suggesting its potential role in vascular remodeling (see below). These different antagonists and agonists bind to BMPs with different affinities, and can preferentially interfere with one family member and not others. For example, noggin binds with strong affinity to BMP-2, BMP-4, and BMP-7, with lower affinity to BMP-6, and not to BMP-9 and BMP10 (David et al. 2008; Song et al. 2010). Also, MGP can either inhibit or enhance the BMP-2 and BMP-4 activity, depending on its concentration (Zebboudj et al. 2002; Yao et al. 2006).

\section{BMP SIGNALING}

BMPs bind as dimers at the cell surface to heterotetrameric receptor complexes that include two types of dual specificity kinase receptors (Table 1, Fig. 1): the BMP type I receptors (i.e., activin receptor-like kinase [ALK]-1, ALK-2, ALK-3, and ALK-6) and the BMP type II receptors (i.e., BMPRII, ActRIIA, and ActRIIB) (Yadin et al. 2016). These type I and type II receptors bind a variety of BMP ligands, whereas the activin type II receptors also bind activins (Upton and Morrell 2009). Regardless of the receptor combination, the type II receptor contains a constitutively active kinase domain, even in the absence of ligand. Binding of intracellular FK506-binding protein (FKBP) 12 acts as a gatekeeper mechanism, setting a threshold for type I receptor activation by the 
M.-J. Goumans et al.

Table 1. Bone morphogenetic protein (BMP) ligands and their receptors

\begin{tabular}{|c|c|c|c|c|}
\hline BMP & Type II & Type I & R-Smad & Coreceptor \\
\hline $\begin{array}{l}\text { BMP-2 } \\
\text { BMP-4 }\end{array}$ & $\begin{array}{l}\text { BMPRII } \\
\text { ACTRIIA/B }\end{array}$ & $\begin{array}{l}\text { ALK-3 } \\
\text { ALK-6 } \\
\text { ALK-3 } \\
\text { ALK-6 }\end{array}$ & $\begin{array}{l}\text { Smadl, 5, } 8 \\
\text { Smadl, 5, } 8\end{array}$ & RGM \\
\hline $\begin{array}{l}\text { BMP-6 } \\
\text { BMP-7 }\end{array}$ & $\begin{array}{l}\text { BMPRII } \\
\text { ACTRIIA/B }\end{array}$ & $\begin{array}{l}\text { ALK-3 } \\
\text { ALK-6 } \\
\text { ALK-2 } \\
\text { ALK-3 } \\
\text { ALK-6 }\end{array}$ & $\begin{array}{l}\text { Smadl, 5, } 8 \\
\text { Smadl, 5, } 8\end{array}$ & RGM \\
\hline $\begin{array}{l}\text { BMP-9 } \\
\text { BMP-10 }\end{array}$ & $\begin{array}{l}\text { BMPRII } \\
\text { ACTRIIA/B }\end{array}$ & $\begin{array}{l}\text { ALK-1 } \\
\text { ALK-2 } \\
\text { ALK-1 }\end{array}$ & $\begin{array}{l}\text { Smadl, 5, } 8 \\
\text { Smadl, 5, } 8 \\
\text { Smad2 }\end{array}$ & Endoglin \\
\hline
\end{tabular}

BMPs bind to a combination of type I and type II receptors resulting in the carboxy-terminal phosphorylation and activation of Smad proteins and Smad-mediated modulation of gene transcription. Although there is redundancy, BMPs have a preference related to which receptor complex they bind and which coreceptor may modulate the signal.

BMP, bone morphogenetic protein; ALK, activin receptor-like kinase, BMPRII, BMP type II receptor; ActRIIA/B, activin type II receptor A or B; RGM, repulsive guidance molecules.

type II receptor in the absence of ligand (Huse et al. 1999).

\section{BMP Receptors}

BMPs are classified into different subgroups based on their sequence similarity and affinities for specific receptors (Table 1) (Bragdon et al. 2011; Katagiri and Watabe 2016). BMP-2 and BMP-4 preferentially bind to ALK-3 and ALK-6 (also known as BMPRIA and BMPRIB, respectively), and BMPRII or ActRIIA/B. BMP-6 and BMP-7 bind to ActRIIA and form a complex with ALK-2, also known as ActRI. BMP-9 and BMP-10 bind with high affinity to ALK-1, also known as TSR-I or SKR3, in combination with BMPRII, ActRIIA, or ActRIIB. Moreover, BMP9 binds ALK-2 only in the presence of a type II receptor, whereas BMP-10 cannot bind to ALK2 (Scharpfenecker et al. 2007; Olsen et al. 2014). Interestingly, ALK-2 can form a heterodimer with other type I receptors, thereby increasing the signaling complexity (Yadin et al. 2016). Various BMPs show different affinities for their receptors. The binding affinities of BMP-9 and BMP-10 for ALK-1 are in the picomolar range, which is exceptionally high (Townson et al. 2012; Kienast et al. 2016) compared with the binding affinities of the other BMPs for their type I receptors (Mahlawat et al. 2012). On the other hand, BMP-9 shows substantial differences with BMP-10 in type II receptor binding. BMP-9 binds most strongly to ActRIIB, and shows weaker binding to BMPRII and weakest binding to ActRIIA, although these data remain to be confirmed in ECs (Townson et al. 2012; Kienast et al. 2016). In contrast, BMP-10 does not show such a clear preference for the different type II receptors (Townson et al. 2012).

\section{BMP Coreceptors}

The binding of a BMP to its receptor can be modulated by coreceptors, which lack an intrinsic signaling motif (Table 1, Fig. 1). Two transmembrane receptors, betaglycan, also called the TGF- $\beta$ type III receptor or T $\beta$ RIII, and endoglin play roles in the vasculature. Betaglycan increases the binding of BMP-2, -4, -7, and -14 to ALK-3 and ALK-6 (Kirkbride et al. 2008), whereas endoglin has been shown to promote or repress signaling via distinct mechanisms that depend on the levels of endoglin and the concentrations of receptors and ligands (ten Dijke et al. 2008). Endoglin interaction with ALK-1 increases the responses to BMP-9 


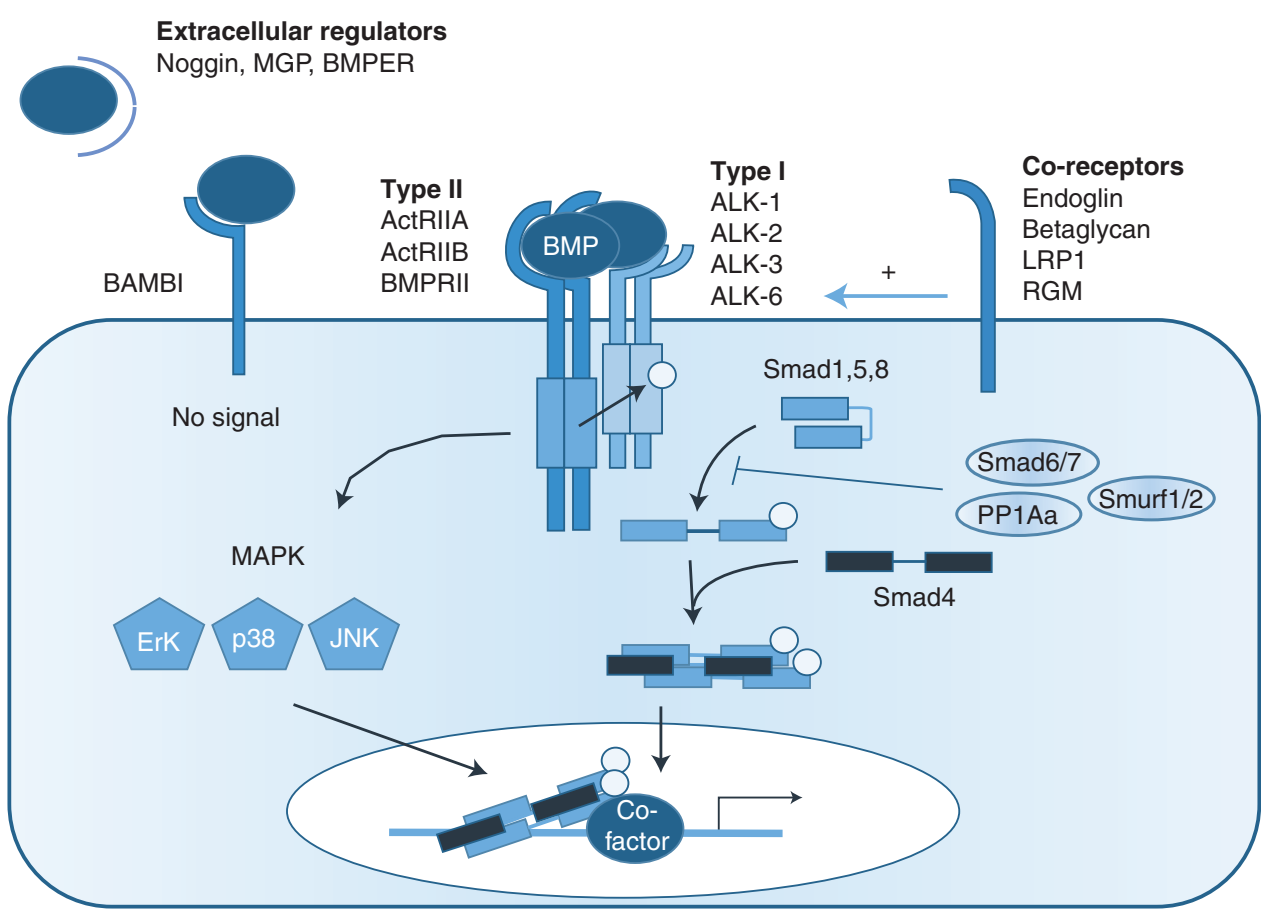

Figure 1. Bone morphogenetic protein (BMP) signaling pathway. Schematic representation of the BMP signaling pathway. BMPs interact with specific type I and type II receptors to form a heterotetrameric complex. Complex formation and ligand binding can be potentiated by a coreceptor-that is, endoglin, betaglycan, lipoprotein receptor-related protein 1 (LRP-1), or repulsive guidance molecule (RGM). After complex formation, the type II receptor phosphorylates the type I receptor, which then carboxy-terminally phosphorylates Smad1, Smad5, and Smad8 (canonical BMP signaling). Phosphorylated Smads propagate the signal via complex formation with Smad4, translocation into the nucleus, and regulation of the expression of target genes. Besides Smad-dependent signaling, BMPs can also transduce signals by mitogen-activated proteins kinases (MAPKs) (noncanonical BMP signaling). Canonical BMP signaling is intracellularly inhibited by inhibitory Smads—-that is, Smad6 and/ or Smad7, E3 ubiquitin ligases, such as Smurf1 or Smurf2, or phosphatases (PPA1 $\alpha$ ). BMPs are extracellularly inhibited from binding to the receptor complex by secreted inhibitors, like noggin, matrix Gla protein (MGP), and the decoy receptor BAMBI. BMP signaling can be extracellularly stimulated or inhibited by BMPER.

and BMP-10 (Blanco et al. 2005; David et al. 2007; Scharpfenecker et al. 2007; Castonguay et al. 2011; Alt et al. 2012). The present model is that endoglin and ALK-1 at the cell surface act together to bind and capture BMP-9, and that subsequent BMP-9 binding to the type II receptor displaces the bound endoglin to form a ligand-bound type I and type II receptor signaling complex. The affinity of BMP-9 for endoglin is in the nanomolar range (Castonguay et al. 2011; Kienast et al. 2016). Endoglin can also form a complex with the TGF- $\beta$ type II receptor, and either promote or inhibit TGF- $\beta$-induced Smad1 and Smad5 phosphorylation by
ALK-1 (Lebrin et al. 2004; Pece-Barbara et al. 2005). The interaction of endoglin with ALK-1 is also enhanced by fibronectin and integrin $\alpha_{5} \beta_{1}$ leading to increases of BMP-9- and TGF- $\beta$-induced phosphorylation of the BMP signaling effectors Smad1, Smad5, and Smad8 (Tian et al. 2012). Endoglin can be shed from the cell surface through the actions of matrix metalloproteinases, and the soluble endoglin ectodomain may thereby act as a released receptor trap for BMPs that can affect vascular remodeling (Venkatesha et al. 2006; Hawinkels et al. 2010; Rathouska et al. 2015; Gallardo-Vara et al. 2016). Soluble endoglin was also shown to scavenge 
M.-J. Goumans et al.

BMP-9 and prevent BMP-9-induced Smad1, Smad5 and Smad8 phosphorylation, whereas it cannot bind TGF- $\beta$ (Gregory et al. 2014).

BMP signaling is potentiated by the glycosylphosphatidylinositol-anchored repulsive guidance molecule (RGM) proteins (Corradini et al. 2009) and low-density lipoprotein receptor-related protein 1 (LRP-1) (Pi et al. 2012), whereas the decoy receptor BMP and activin membrane-bound inhibitor (BAMBI) sequesters ligands from type I receptors and inhibits BMP signaling in ECs (Onichtchouk et al. 1999; Guillot et al. 2012).

\section{Heterotetrameric BMP Receptor Complexes}

Although BMP receptors are widely expressed, not all cell types express all BMP receptors, and the type I-type II receptor combinations for each BMP may therefore be cell-type specific. The available type I, type II, and type III receptors will determine which BMP will preferentially signal and what the cellular response will be. ALK-2 and ALK-3 are widely expressed, whereas ALK-1 is more selectively expressed on ECs, and ALK-6 is expressed by only a few cell types (Garcia de Vinuesa et al. 2016). BMPRII and ActRIIA are ubiquitously expressed, whereas ActRIIB expression is restricted to certain cell types, including ECs. Among these type II receptors, only BMPRII is highly expressed in ECs. The high binding affinity of BMP-9 and BMP-10 for ALK-1 and BMPRII, together with the high ALK-1 and BMPRII expression levels in ECs, may explain the major role of these two BMPs in angiogenesis. ALK-1 may also form a complex with ActRIIA or ActRIIB enabling BMP-9- or BMP-10-induced activation (David et al. 2007; Scharpfenecker et al. 2007). BMP-2 and BMP-4 bind to ALK-3 or ALK-6; however, because ALK-3 and ALK-6 are not highly expressed in ECs, BMP-2 and BMP-4 are unlikely to induce strong responses in these cells. BMP-6 and BMP7 bind to ActRIIA and ALK-2, thus inducing activation of Smad 1 and Smad5. VSMCs express BMPRII and ALK-3 at high levels, whereas ALK1 and endoglin are not highly expressed in VSMCs under physiological conditions (Upton et al. 2008). BMPRII and ALK-3 mediate re- sponses to BMP-2 and BMP-4 in pulmonary arterial (PA) smooth muscle cells (SMCs). ALK-1, ALK-2, BMPRII, ActRIIA, and ActRIIB are also expressed in cultured murine VSMCs, and treatment with BMP-9 induces calcification (Zhu et al. 2015).

\section{BMP Signal Transduction}

On formation of a ligand-receptor complex, type II receptors activate type I receptors through phosphorylation of serine and threonine residues in their glycine-serine-rich (GS) domain. Activated type I receptors phosphorylate and thus activate the receptor-regulated Smads (R-Smads), which then form heteromeric complexes with the common mediator Smad, Smad4 (Fig. 1) (Hill 2016; Xu et al. 2016). These complexes translocate to the nucleus where they regulate target gene transcription by binding to Smad-binding elements (SBEs) and interacting with other coactivators or corepressors (Ross and Hill 2008). The specific type I receptor in the ligand-receptor complex determines which R-Smads are activated. Most BMPs induce phosphorylation of Smad1, Smad5, and Smad8 (also named Smad9), although, in pulmonary ECs, BMP-9 can also activate Smad2, which is normally associated with TGF- $\beta$ signaling (Upton et al. 2009). The underlying mechanism for this Smad2 response remains to be determined. The Smad-dependent pathway is directly activated by the type I receptor, although Smads may also be activated by alternative mechanisms that must be further explored. Indeed, TGF- $\beta$-activated kinase 1 (TAK1), which is generally thought to be involved in Smad-independent pathways, has been reported to phosphorylate Smad1 at the carboxyl terminus (Shim et al. 2009).

On ligand binding, BMP receptors can also activate non-Smad pathways that are important for correct vascular system establishment (Zhang 2017). Such non-Smad pathways include signaling by mitogen-activated proteins kinases (MAPKs), such as p38, Erk, and JNK (Gallea et al. 2001; Guicheux et al. 2003), the phosphatidylinositol 3-kinase (PI3K)-Akt pathway and small Rho-like GTPases (Gamell 
et al. 2008). Cross-talk between VEGF and BMP-6 can enhance p38 MAPK activation and inhibit Akt activation, but does not impact the carboxy-terminal phosphorylation of Smad1, Smad5 and Smad8 or Erk MAPK activation (Li et al. 2015a). BMP-9 inhibits JNK activation in ECs (Long et al. 2015). Endoglin and G $\alpha$ interacting protein carboxyl terminus interacting protein (GIPC)-mediated trafficking of $\mathrm{PI} 3 \mathrm{~K}$ regulates endothelial signaling and function (Lee et al. 2008, 2012). The BMPRII carboxy-terminal extension also interacts with effectors that can be involved in non-Smad signaling (Hassel et al. 2004; Chan et al. 2007). BMP signaling pathways interact with other growth factor pathways that are essential for vascular development and homeostasis, including the FGF, Notch, and WNT pathways, and possibly also the Hippo pathway (Guo and Wang 2009; Garcia de Vinuesa et al. 2016). BMPs, together with other vascular signaling pathways, also interact with vascular endothelial (VE) cadherin, an essential component of endothelial adherent junctions, which plays a crucial role in vascular permeability (Weis and Cheresh 2005; Lagendijk and Hogan 2015). It has been shown that VE-cadherin can associate with ALK-2 and BMPRII in a BMP-6-dependent manner (Benn et al. 2016). BMP-6 induces c-Src phosphorylation leading to VE-cadherin internalization and an increase in vessel permeabilization.

\section{BMP Signal Termination}

As the duration of BMP signaling will determine its effects in vascular development and disease, it has to be tightly controlled (Fig. 1). BMP signaling can be terminated in many ways. Inhibitory Smads (I-Smads, Smad6, and Smad7) inhibit BMP signaling through various mechanisms, including interfering with the interactions between R-Smads and type I receptors, downregulation of cell surface type I receptors, prevention of complex formation by R-Smads and co-Smads, and transcriptional regulation in the nucleus (Miyazawa and Miyazono 2016). For example, inhibitory Smads can recruit the Smad E3 ubiquitin ligases Smurf1 or Smurf2 to the type I receptors, thus promoting receptor degradation (Kavsak et al. 2000; Ebisawa et al. 2001; Murakami et al. 2003). Smad6 and Smad7 can also recruit protein phosphatases, such as protein phosphatase $1 \alpha(\mathrm{PPA} 1 \alpha)$, to dephosphorylate ALK-1 (Valdimarsdottir et al. 2006). Interestingly, Smad6 and Smad7 were originally identified as vascular Smads because their expression is induced in ECs by laminar shear stress (Topper et al. 1997). The expression of both inhibitory Smads is induced by BMPs, thus creating a negative feedback loop (Ishisaki et al. 1999). Smad7 inhibits both BMP and TGF$\beta$ signaling by competing with recruitment of phosphorylated R-Smads and by promoting the degradation of the type I receptors, whereas Smad6 more selectively inhibits BMP signaling by recruiting Smurf1 to BMP type I receptors or by competing with R-Smad for binding to Smad4 (Hata et al. 1998; Murakami et al. 2003).

\section{BMP SIGNALING MUTATIONS IN VASCULAR DISEASES}

Two human genetic vascular disorders have been linked to mutations in BMP signaling components showing that BMPs are key players in vascular biology. Hereditary hemorraghic telangiectasia (HHT) or Osler-Weber-Rendu syndrome has been linked mostly to mutations in $E N G$, the gene encoding endoglin, and in ACVRL1, which encodes the ALK-1 receptor. The second vascular disease caused by mutations in a BMP signaling component is hereditary pulmonary arterial hypertension (hPAH). Mutations in BMPR2, and occasionally in $A C V R L 1$ or ENG, have been linked to hPAH. Fibrodysplasia ossificans progressiva (FOP) is a rare autosomal-dominant disorder that is mainly characterized by episodic heterotopic ossification (HO) of muscle, fascia, ligaments, and tendons. FOP is driven by activating mutations in ACVR 1 in the coding region of the ALK2 intracellular domain. It is under debate whether this disease categorizes as a vascular disease.

\section{Hereditary Hemorrhagic Telangiectasia}

The first report describing that disrupting BMP signaling can cause a vascular disorder was the 
M.-J. Goumans et al.

identification of mutations in $E N G$ that led to the haploinsufficient vascular disease HHT1 (Fig. 2) (McAllister et al. 1994). Soon after, mutations in ACVRL1, which encodes ALK-1, were identified in HHT2 (Johnson et al. 1996). Several years later, SMAD4 mutations in combined juvenile polyposis-HHT syndrome (JPHHT) were reported (Gallione et al. 2004). Mutations in GDF2, which encodes BMP-9, have now also been described in a related form of HHT, HHT5 (Wooderchak-Donahue et al. 2013; Hernandez et al. 2015). HHT is a rare autosomal-dominant vascular disorder (incidence of 1/8000) (McDonald et al. 2015), which is characterized by frequent epistaxis, skin and mucosa telangiectasia, arteriovenous malformations (AVMs) in the lungs, liver or brain, and hemorrhages associated with these vascular lesions (Dupuis-Girod et al. 2010; Shovlin 2010). HHT1 patients more commonly show pulmonary and cerebral AVMs, whereas HHT2 patients show higher incidences of hepatic AVMs and gastrointestinal telangiectasia (Letteboer et al. 2006; Lesca et al. 2007). These differences may be partly explained by the differential distribution and expression levels of BMP signaling components in these tissues, suggesting overlapping but nonidentical functions for endoglin and ALK-1. AVMs are thought to arise from enlargement of capillary vessels, creating a shunt between an artery and a vein, although the molecular mechanism is still not completely understood (Fig. 2) (Park et al. 2009). It has been proposed that idiopathic AVM and Notch-induced AVMs are distinct from those of HHT (Peacock et al. 2016).

\section{Pulmonary Arterial Hypertension}

The second vascular disease reported with mutations in BMP signaling is pulmonary arterial hypertension (PAH), which is mainly due to mutation in BMPR2, which encodes the BMPRII receptor (Deng et al. 2000; Lane et al. 2000). PAH is a rare vascular disorder with an incidence of $1 / 25,000$, and is characterized by an elevated mean resting pulmonary arterial pressure of $>25 \mathrm{mmHg}$, with normal left atrial pressure and high pulmonary vascular resis- tance (Simonneau et al. 2013). The increased pulmonary vascular resistance in PAH is attributed to small pulmonary artery constrictions caused by profound vascular remodeling (Guignabert et al. 2015). ECs, VSMCs, and fibroblasts show aberrant proliferation and resistance to apoptosis, resulting in reduced luminal diameter, increased blood pressure and, ultimately, lethality from right ventricular failure (Fig. 3).

Three forms of hypertension have been defined: idiopathic PAH (iPAH), familial or heritable PAH (hPAH), and environmental PAH. Approximately $70 \%$ of hPAH patients show mutations in the BMPR2 gene, and $\sim 25 \%$ of sporadic iPAH cases show de novo BMPR2 mutations. Mutations in BMPR2 have been identified in nearly all exons of the coding sequence-including exons encoding parts of the ligand binding domain, kinase domain, and cytoplasmic tail. The vast majority of BMPR2 mutations are frame-shift mutations leading to a premature stop codon and resulting in haploinsufficiency owing to nonsense-mediated decay of mutant BMPRII mRNA transcripts (Fessel et al. 2011). The remaining mutations lead to loss of function via a variety of mechanisms, including loss of kinase activity and impairments of receptor folding and trafficking ( $\mathrm{Ru}-$ darakanchana et al. 2002). A meta-analysis of data of 1550 patients with PAH revealed that PAH patients harboring a BMPR2 mutation present at a younger age a more severe disease and carry an increased risk of death (Evans et al. 2016). There is no full penetrance of the disease onset, and women carrying a BMPR2 mutation show a greater incidence of PAH (Shapiro et al. 2012), likely caused by estrogen-induced inhibition of BMPRII signaling in VSMCs (Mair et al. 2015).

Although mutations in ACVRL1 usually cause HHT2, cases of severe PAH that are indistinguishable from $\mathrm{iPAH}$ have been documented in families segregating with HHT (Harrison et al. 2003; Girerd et al. 2010). Of note, mutations in the genes encoding endoglin (ENG), Smad8 (SMAD9), and BMP-9 (GDF2) have also been described in PAH (Machado et al. 2015; Wang et al. 2016a). As in HHT, 

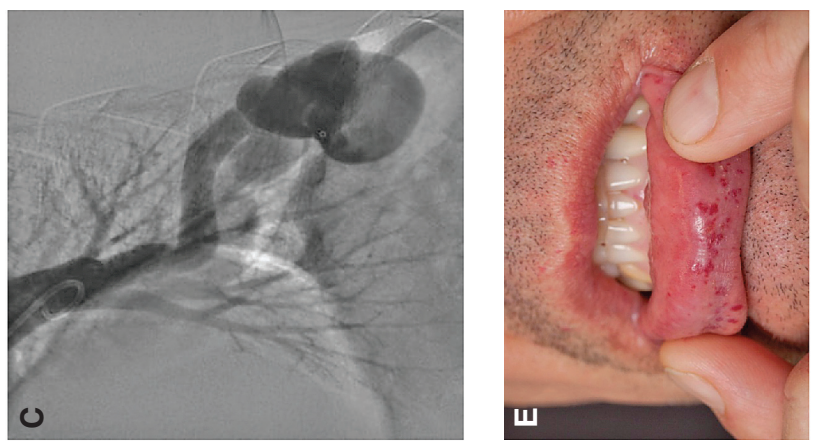

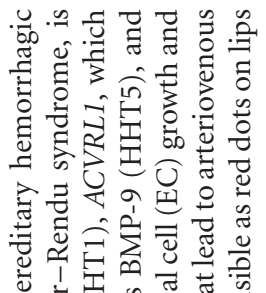

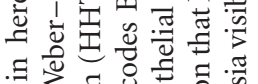
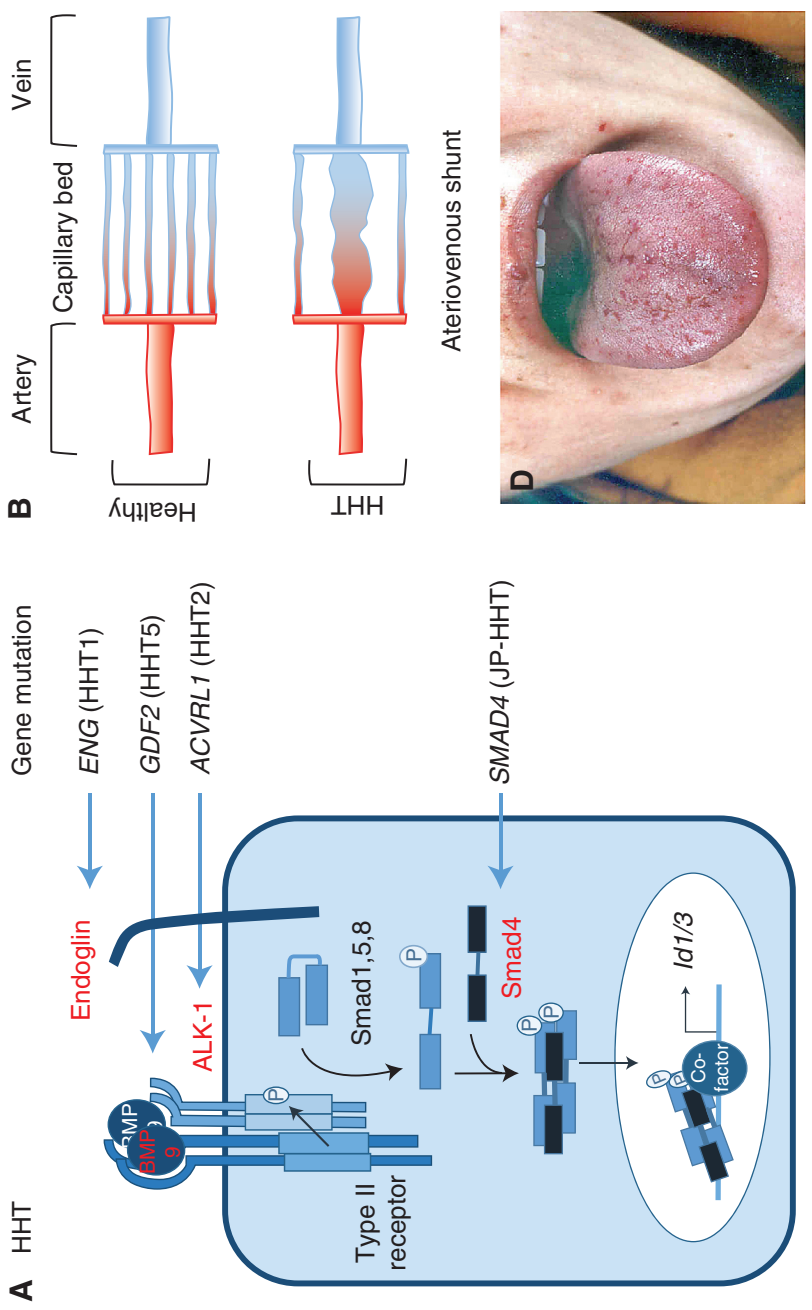

늘

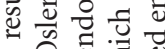

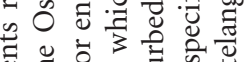

$\exists$ 就

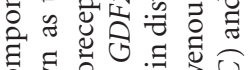

ठํ

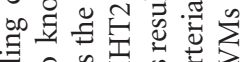

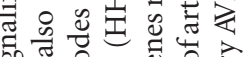
कo

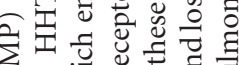

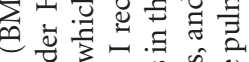

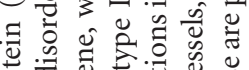
象:

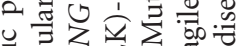

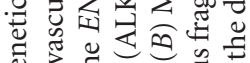

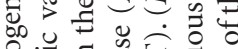

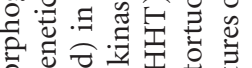

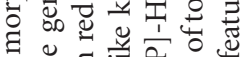

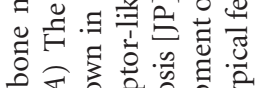

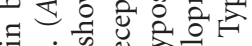

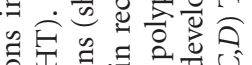

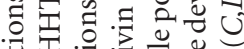

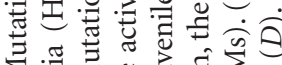

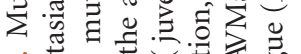
त

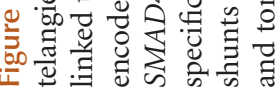


M.-J. Goumans et al.

A PAH

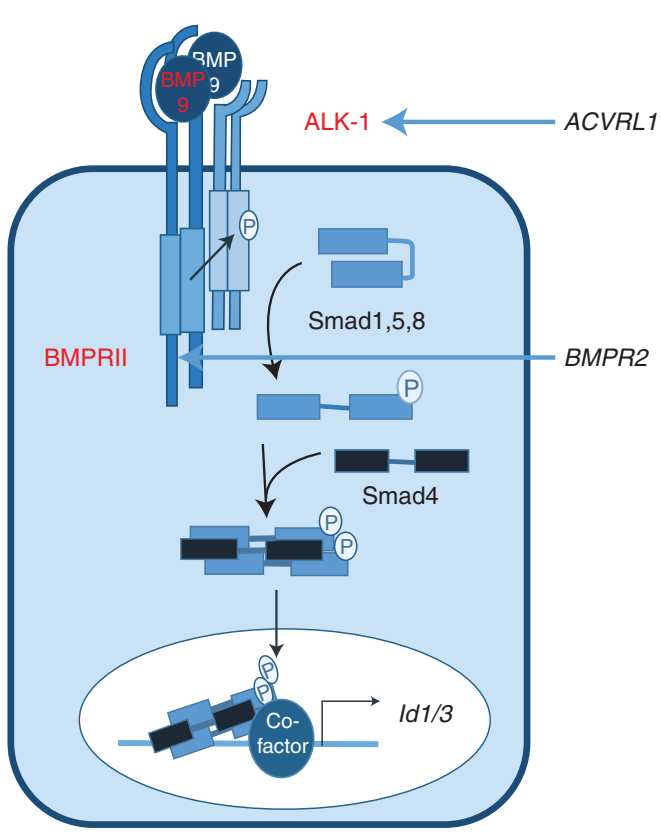

B
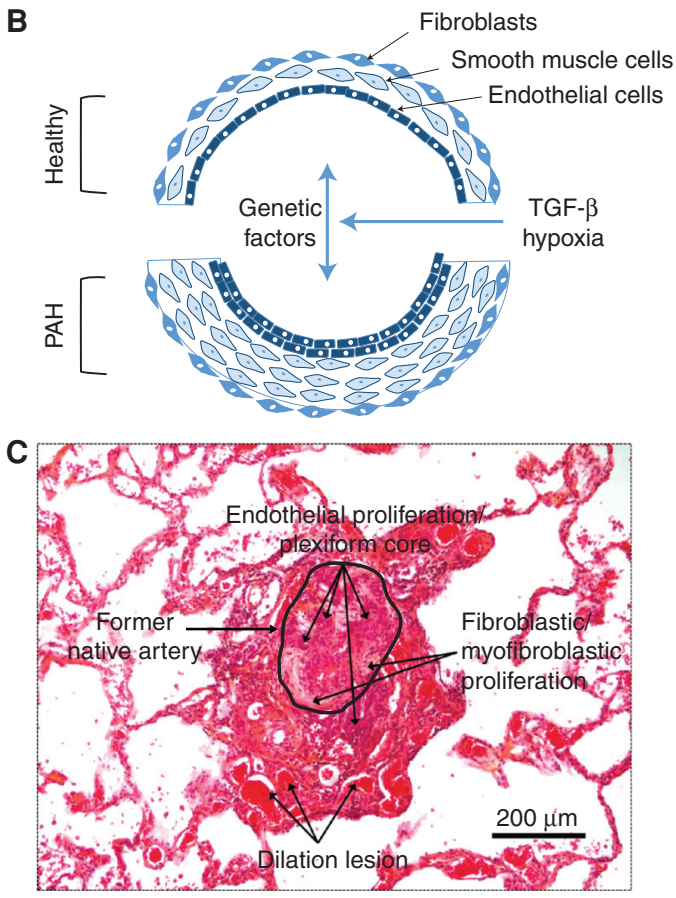

Figure 3. Mutations in bone morphogenetic protein (BMP) signaling cascade results in pulmonary arterial hypertension (PAH). (A) The genetic vascular disorder PAH has been linked to mutations mainly in the BMPR2 gene for the BMPRII receptor, as well as the ACVRL1 gene, encoding the activin receptor-like kinase (ALK)-1 receptor (mutations indicated in red). Recently, a mutation in GDF2, encoding BMP-9, was described in a PAH patient. Rare cases of mutation in ENG or SMAD8 have also been described but are not shown here. $(B)$ Mutations in these genes increase endothelial cell (EC) and vascular smooth muscle cell (VSMC) proliferation, resulting in a multilayered vessel that will lead to vessel obstruction. (C) Plexiform lesion distal to a pulmonary artery in the lung of a patient with idiopathic $\mathrm{PAH}$, which is characteristic for plexogenic pulmonary arteriopathy. The section is stained with hematoxylin and eosin.

BMP-9 and BMP-10 signaling via BMPRII and ALK-1 likely plays a central role in $\mathrm{PAH}$ pathobiology, implicating ECs as an important cell type in the initiation of both diseases (Morrell et al. 2016).

Despite advances in our understanding of the pathogenesis of these genetic diseases in humans, many important questions remain unanswered. For example, it is unknown how loss-offunction mutations in BMPR2, ACVRL1, or ENG can cause a disease that seems confined to pulmonary, liver, or brain vascular beds. We also lack an explanation for the variable penetrance of these diseases - with $\sim 100 \%$ penetrance for carriers of HHT mutations compared with only $20 \%$ for carriers of PAH mutations. Genetic studies in mice have clarified some of these issues and guide our design of improved targeted therapies for patients. Indeed, for most of the genes encoding BMP signaling mediators that are found to be mutated in vascular diseases, genetic deletion results in strong and often lethal vascular phenotypes in mice, further supporting the view that this pathway plays a role in vascular development. Further insights into the disease mechanisms have been obtained using heterozygote animal models of tissue-specific deletions, which mimic a human patient's phenotype. These analyses have characterized different (non-)cell-autonomous players involved in disease development. In the following section, we will discuss the mouse models that have helped elucidate the role of BMPs in the human pathologies. 


\section{LOSS-OF-FUNCTION ANIMAL MODELS IN BMP SIGNALING LINKED TO VASCULAR DISEASES}

\section{Defects in Blood Vascular Remodeling}

In mice, genetic deletion of Eng, Acvrl1, or Smad5 causes embryonic lethality because of cardiovascular system defects (Goumans and Mummery 2000), suggesting that these genes function in a common pathway. Embryos deficient for Eng (Li et al. 1999; Arthur et al. 2000; Bourdeau et al. 2000), Acvrl1 (Oh et al. 2000; Urness et al. 2000), or Smad5 (Chang et al. 1999; Yang et al. 1999) each show impaired yolk sac and embryonic vascular development, resulting in embryonic lethality around embryonic day (E) 11.5. The phenotypes look remarkably similar, but there are subtle differences. Endoglin-deficient embryos do not have a layer of VSMCs covering their major vessels at E9.5 ( $\mathrm{Li}$ et al. 1999), and this VSMC developmental deformity precedes the vascular remodeling defects. Eng ${ }^{-/-}$ECs produce less TGF- $\beta 1$, hampering the recruitment of mesenchymal cells and their differentiation into pericytes and VSMCs, and thus preventing formation of the VSMC layer (Carvalho et al. 2004). In addition to this vascular phenotype, Eng ${ }^{-/-}$embryos also show an enlarged ventricle and outflow tract, abnormal cardiac looping, and truncal cushions with a disorganized endothelial layer-which are all signs of abnormal cardiac development (Arthur et al. 2000). Acvrl1 ${ }^{-/-}$ embryos also show large vessel dilation and delayed VSMC differentiation and migration. Unlike Eng ${ }^{-/-}$embryos, Acvrl1 ${ }^{-/-}$embryos show excessive fusion of capillary networks in the embryo proper. Furthermore, they form AVMs because of fusion of major arteries and veins ( $\mathrm{Oh}$ et al. 2000; Urness et al. 2000; Park et al. 2008).

Both BMP-9 and BMP-10 are physiological ligands of ALK-1. This finding, coupled to the fact that $\mathrm{Acvrl1}^{-/}$mice show a strong vascular phenotype and $B m p 9^{-/-}$mice show normal blood vascular development, has led to a reevaluation of $\mathrm{Bmp} \mathrm{O}^{-/-}$mice that were described to have a cardiac phenotype (Chen et al. 2004). Bmp10-deficiency leads to defects in the embryo proper, including absent vitelline vessels, a stalled vascular development at the primary capillary plexus stage, and presence of AVMs (Chen et al. 2013), which are reminiscent of the vascular phenotype observed in Acvrl1 $^{-/-}$embryos (Oh et al. 2000; Urness et al. 2000). The same research group generated a Bmp9 knockin mouse line, in which the Bmp10 coding region was replaced with that of $B m p$ 9. These mice showed normal vascular development up to E16.5, supporting the view that BMP-9 and BMP-10 are functionally interchangeable during vascular development. However, at E17.5, the heart was enlarged with pronounced ventricular septal defects consistent with previous reports showing that BMP-10 is critical for heart development (Chen et al. 2004). Interestingly, ALK-1 and BMP-10 are first expressed at E8.5 (Seki et al. 2003; Chen et al. 2013), whereas BMP-9 expression begins 2 days later, at E10.5 (Chen et al. 2013). Collectively, these data show that BMP-10 plays a crucial role in early vascular development. Moreover, at the onset of BMP-9 synthesis, both BMPs are interchangeably involved in blood vascular development, and in ensuring vascular quiescence. In contrast, BMP-10 plays a specific role in heart development, likely because of the different affinities of BMP-9 and BMP-10 for their receptors (Townson et al. 2012).

The BMP pathway is controlled by extracellular BMP modulators, such as BMPER and twisted gastrulation (TSG), which finely tune the BMP-induced proangiogenic events and maintain vascular homeostasis (Heinke et al. 2013). In the embryonic heart, BMPER expression is restricted to the ECs and the endothelium-derived cushions. Bmper ${ }^{-/}$mice die at birth because of skeletal and kidney defects (Ikeya et al. 2006), and they have coronary heart anomalies because of impaired migration of ventricular ECs (Dyer et al. 2015). Furthermore, these hearts develop mitral valve prolapse (Willis et al. 2013) because of dysregulation of endothelial-to-mesenchymal transition (EndMT) in the cardiac cushions (Dyer et al. 2015). Finally, BMPER was shown to coregulate the BMPmediated inflammation associated with laminar and oscillatory shear stress (Pi et al. 2012) and may regulate the osteoblast-like differenti- 
M.-J. Goumans et al.

ation of human coronary artery VSMCs (Satomi-Kobayashi et al. 2012). Interestingly, $M g p^{-/-}$mice develop AVMs of the lung and kidney, which are characteristic of vascular dysplasia HHT (Yao et al. 2013).

Another modulator of BMP signaling is TAK1, which is activated in response to both BMP (Shibuya et al. 1998) and TGF- $\beta$ (Yamaguchi et al. 1995) stimulation, as well as interleukin-1 (IL-1) and several other unrelated cytokines. Among other defects, Tak1 ${ }^{-/-}$embryos show dilated blood vessels associated with the loss of smooth muscle differentiation at mid-gestation (Jadrich et al. 2006). Endothelial-specific Takl deletion reveals the importance of TAK1 for embryonic EC survival and migration (Morioka et al. 2012). The phenotype of Tak1 deletion in mice is strikingly similar to that of Acvrl1 and Eng deletion, which is in line with the notion that TAK1 is an effector of this pathway. Consistently, TAK1 overexpression can rescue the vascular defect elicited by silencing Acvrll expression using morpholino oligonucleotides in zebrafish (Jadrich et al. 2006).

\section{Defects in Lymphatic Vascular Remodeling}

Embryonic lymphatic ECs (LECs) transdifferentiate from embryonic venous ECs through the cooperation of the SOX18 and COUP-TFII transcription factors to promote PROX1 expression (Francois et al. 2008; Yang et al. 2012; Aranguren et al. 2013; Srinivasan et al. 2014). Migration of PROX1-expressing cells from embryonic veins and the subsequent podoplaninmediated lymphaticovenous separation require VEGF-C (Zheng et al. 2014). Following establishment of the primary lymphatic vasculature, lymphatic vessels undergo further remodeling to form a functional and hierarchical lymphatic vessel network comprising lymphatic capillaries, precollectors, and collecting vessels. Fluid is taken up by lymphatic capillaries via discontinuous VE-cadherin-positive button junctions. The fluid passes into precollectors that contain intraluminal valves to prevent retrograde flow, ensuring unidirectional flow of lymph to the blood circulation (Coso et al. 2014; Vittet 2014; Yang and Oliver 2014).
The essential role of BMP signaling in the lymphatic development of mice was first shown by the disrupted lymphatic development observed in the intestine and tail of newborn mice following injection of the extracellular domain of ALK-1 fused to the Fc fragment of human IgG1 (ALK1-FC) or of a blocking antiALK-1 antibody (Niessen et al. 2010). Mice with an induced genetic deletion of Acvrl1 have enlarged lymphatic vessels within the intestine, cornea, and diaphragm, consistent with the antiproliferative role of ALK-1 in postnatal lymphatic development (Yoshimatsu et al. 2013). $B m p 9^{-/-}$mice also show enlarged lymphatic capillaries and collecting lymphatic vessels in mesentery, ear skin, and back skin, suggesting that BMP-9 could be a major ALK-1 ligand required for lymphatic vascular development (Levet et al. 2013; Yoshimatsu et al. 2013). Furthermore, $B m p 9^{-/-}$mice show reduced numbers of lymphatic valves and decreased drainage efficiency (Levet et al. 2013), whereas adenovirus-mediated BMP-9 overexpression diminishes inflammatory lymphangiogenesis in mice (Yoshimatsu et al. 2013). No lymphatic defects have been described so far in $B m p 10^{-/-}$mice, suggesting a specific role for BMP-9 signaling through ALK-1 in lymphatic development. Other studies report that BMP-2 signaling through Alk-3, Alk-3b, BMPRIIa, BMPRIIb, and Smad5 can decrease the number of LECs in zebrafish (Dunworth et al. 2014; Kim and Kim 2014). However, zebrafish and mice may show different context-dependent molecular and cellular roles for BMP signaling in vascular remodeling.

\section{GENETICALLY MODIFIED MOUSE MODELS FOR HUMAN VASCULAR DISEASES AND TREATMENTS}

Mice homozygous for null mutations in Eng or Acvrl1 are embryonic lethal at mid-gestation because of cardiovascular defects. Although these models are very helpful for determining the function of endoglin or ALK-1, they do not phenocopy the human disease. Therefore, heterozygous or inducible homozygous null mice, which have grown normally to adulthood before deletion, may be very useful models of BMP- 
related genetic vascular diseases. These models will also aid the design of new treatments.

\section{Hereditary Hemorrhagic Telangiectasia}

Mice that are heterozygous for mutations in Acvrl1 or Eng develop vascular abnormalities that resemble the clinical pathology of HHT (Bourdeau et al. 1999; Srinivasan et al. 2003; Torsney et al. 2003). These phenotypes are, like in patients, quite variable and mild, occur with a late onset, and depend on the genetic background (observed in 129/Ola background only), suggesting that additional factors are required for HHT development, such as genetic modifiers or environmental triggers (Bourdeau et al. 1999; Torsney et al. 2003). Angiogenesis has been proposed to act as an additional trigger or secondary hit, because $\mathrm{Eng}^{+/-}$and $\mathrm{Acvrl1}{ }^{+/-}$ mice injected with VEGF-expressing adenoviral particles show increased vascular dysplasia (Xu et al. 2004; Hao et al. 2010). Homozygous deletion of Eng or Acvrl1 using cell type-specific or time-dependent Cre drivers results in consistent and robust AVMs in a pro-angiogenic and inflammatory environment (e.g., VEGF administration, normal angiogenesis in early postnatal life, inflammation, wounding) (Park et al. 2009; Walker et al. 2011; Choi et al. 2012, 2014). The use of endothelium-specific expression of Cre recombinase clearly shows that ECs are the prime cell type affected by the mutation, because no AVMs are detected when the loss of Eng or Acvrl1 occurs in VSMCs, pericytes or macrophages (Choi et al. 2014; Garrido-Martin et al. 2014).

The neonatal retina is initially avascular, and the vascular plexus develops during the first week of life in a stereotypical fashion (Fruttiger 2007). The neonatal mouse retina is a widely used model for studying angiogenesis because it allows a detailed study of the different stages of vascular development. This retinal angiogenesis model was used to show the roles of ALK-1 and endoglin in retinal vascular differentiation (Mahmoud et al. 2010; Tual-Chalot et al. 2014). Induced endothelium-specific Eng or Acvrl1 inactivation result in delayed vascular remodeling of the retina capillary plexus. Admin- istration of ALK1-FC as a ligand trap in wildtype mice (Larrivee et al. 2012), or anti-BMP-10 antibody in $B m p 9^{-/-}$mice, or neutralizing anti-BMP9 and anti-BMP10 in wild-type mice further revealed that both BMP-9 and BMP-10 are involved in retinal angiogenesis and can modulate the Notch pathway (Ricard et al. 2012; Chen et al. 2013; Baeyens et al. 2016; Ola et al. 2016; Ruiz et al. 2016). It has been shown that Smad1 and Smad5 are required for modulation of the Notch pathway during angiogenesis (Moya et al. 2012).

Together, these mouse models led to the identification of several key events in HHT development: (1) ECs are the critical cell type involved in HHT; (2) loss of Acvrl1 or Eng is not required in every EC of an AVM, because mosaicism can account for the phenotype (TualChalot et al. 2014); and (3) genetic modifiers may influence the susceptibility to HHT disease (Bourdeau et al. 2001). Studies in these mouse models also led to the proposal that AVM formation requires three events: (1) heterozygosity of Eng or Acvrl1 mutations; (2) loss of heterozygosity by somatic mutation, which has not yet been described in patients, or alternatively by protein shedding of endoglin, or potentially also by ALK-1; and (3) an additional proangiogenic or inflammatory trigger.

Heterozygous and homozygous Eng and Acvrl1 mice are also used in experiments to test potential new HHT treatments. Thalidomide treatment can restore the reduced VSMC coverage of vessels in $\mathrm{Eng}^{+/-}$mice (Lebrin et al. 2010). Anti-VEGF treatment of inducible Acvrl1 ${ }^{-/-}$mice has led to attenuation of brain AVMs (Walker et al. 2012), and topical application of a VEGF-neutralizing antibody shortly after wounding can prevent AVM formation, block the progression of established AVMs, and even induce regression of early AVMs in mice with induced endothelial Acvrl1 inactivation (Han et al. 2014). For an extensive discussion on this topic we refer to the review by Tual-Chalot et al. (2015). In agreement with the results obtained in animal models, therapeutic approaches to block angiogenesis, such as antiVEGF antibodies, thalidomide, or PI3-kinase inhibition, have been developed and show ben- 
M.-J. Goumans et al.

eficial effects in HHT patients (Lebrin et al. 2010; Dupuis-Girod et al. 2012; Ola et al. 2016). Taken together, these results support the hypothesis that HHT pathogenesis is caused by an enhanced response to angiogenic cues when ALK-1 or endoglin expression are diminished (Choi et al. 2013).

\section{Pulmonary Arterial Hypertension}

Mice heterozygous for Bmpr2 do not develop or show only minimal signs of PAH without additional stimuli (Beppu et al. 2004; Song et al. 2005; Long et al. 2006). Expression of a dominant-negative form of BMPRII represses BMPRII signaling in smooth muscle cells and causes elevated right ventricle systolic pressure (RVSP) (West et al. 2004). Interestingly, $B m p r 2^{-1-}$ deficiency in pulmonary ECs (pECs) elicits PAH in some mice (Hong et al. 2008), providing in vivo evidence that absence of BMPRII signaling in ECs is sufficient to cause a predisposition to $\mathrm{PAH}$. Interference with BMP signaling at the level of the Smads has shown that EC- or VSMC-specific Smad1 deletion yields mutant mice with elevated pulmonary pressure, right ventricular hypertrophy, and thickened pulmonary arterioles (Han et al. 2013). Smad $8^{-1-}$ mice show a defective pulmonary vasculature (Huang et al. 2009). Additionally, VSMC-specific homozygous replacement of the wild-type Bmpr2 sequence with $B m p r 2^{\mathrm{R} 899 \mathrm{X}}$, corresponding to the $B M P R 2^{\mathrm{R} 899 \mathrm{X}}$ mutation in a PAH patient that results in a truncated BMPRII, induces an increase of RVSP in approximately one-third of the transgenic mice (West et al. 2008). Additionally, heterozygous $B m p r 2^{+/ R 899 X}$ mice developed RVSP by six months of age (Long et al. 2015). Signs of pulmonary hypertension have also been described in heterozygote $\mathrm{Acvrll}^{+/-}$or $\mathrm{Eng}^{+/-}$mice (Toporsian et al. 2010; Jerkic et al. 2011).

Because mice rarely develop pronounced pulmonary hypertension and their vessels are difficult to image and catheterize, rat models are often preferred for studies of PAH. Several rat models of PAH have been developed using environmental induction (e.g., chronic hypoxia, monocrotaline injection, or chronic hypoxia combined with VEGF receptor inhibition using the SU-5416 kinase inhibitor). These models show pronounced pulmonary hypertension with plexiform lesions and right ventricular hypertrophy (Gomez-Arroyo et al. 2012; Nicolls et al. 2012; Dickinson et al. 2013). Strain-specific differences in the SU-5416 rat model of $\mathrm{PAH}$ have been reported, supporting the notion that genetic modifiers play an important role in the PAH phenotype (Jiang et al. 2016a). A Bmpr2 mutant rat model has been generated that carries a heterozygous 140-bp deletion in the first Bmpr2 exon (Bmpr2 $\left.2^{\Delta 140 \mathrm{Ex} 1 /+}\right)$, as identified in a PAH patient (Ranchoux et al. 2015). Although this rat does not spontaneously develop the hemodynamic features of pulmonary hypertension, by three months of age, it displays intense pulmonary vascular remodeling and neomuscularization of intraparenchymal distal arterioles (Ranchoux et al. 2015). Further analyses will reveal whether this genetic rat model will be a useful model for PAH. No existing single model can recapitulate the many diverse forms of PAH; however, they do show endothelial dysfunction, an imbalance of proliferation and apoptosis, and a glycolytic metabolic profile (Maarman et al. 2013; Tuder et al. 2013; Lawrie 2014; Rabinovitch et al. 2014).

Experimental PAH animal models have already been successfully used to test new therapeutic approaches. To date, two approaches to enhance BMP signaling in animal models are showing great promise; however, several questions remain unanswered and further work is needed (Guignabert et al. 2016). In animals with experimentally induced pulmonary hypertension, treatment with either FK506/tacrolimus (Spiekerkoetter et al. 2013) or BMP-9 (Long et al. 2015) reverse the established PAH. Tacrolimus treatment has also shown some benefits in endstage PAH patients (Spiekerkoetter et al. 2015).

\section{Fibrodysplasia Ossificans Progressiva}

FOP is a rare autosomal-dominant disorder that is mainly characterized by episodic heterotopic ossification (HO) of muscle, fascia, ligaments, and tendons. FOP is driven by ACVR 1 mutations in the coding region of the ALK-2 
intracellular domain (Fig. 4). The most common mutation, accounting for $\sim 97 \%$ of cases, is a gain-of-function $\operatorname{Arg} 206 \mathrm{His}(\mathrm{R} 206 \mathrm{H}) \mathrm{ami}$ no acid change in the ALK-2 intracellular juxtamembrane GS subdomain (Shore et al. 2006). A mouse model carrying the human R206H mutation in the Acvrl gene confirmed that this mutation can lead to hyperactivation of Smad signaling, thus identifying an underlying molecular mechanism for the development of this disease. Normally, ALK-2, together with the type II receptors, bind activin but the resulting complex does not stimulate Smad1/5/8 phosphorylation, thus activin acts as an inhibitor of canonical BMP-mediated signaling through ALK-2. However, the R206H variant of ALK-2 responds to activin, inducing signaling via Smad1 and Smad5 (Hatsell et al. 2015). This has led to a new therapeutic approach using a neutralizing activin A antibody that prevents heterotopic ossification in $A c v r 1^{\mathrm{R} 206 \mathrm{H}}$ mice (Hatsell et al. 2015). Interestingly, ECs are incorporated into the heterotopic cartilage and bone of FOP patients, which was not observed in the bone of healthy controls (Medici et al. 2010). Furthermore, the ACVR1 mutation and resulting activation of ALK-2 signaling in ECs leads to EndMT, and the newly generated mesenchymal-like cells can further differentiate into osteoblast-like cells (Fig. 4). This effect is mediated by TGF- $\beta 2$ and BMP-4, but not BMP-7, in a manner dependent on ALK-2 and ALK-5. These data support the idea that BMP-dependent vascular dysfunction could be important in the development of FOP.

\section{BMP-RELATED VASCULAR DISEASES WITHOUT MUTATIONS IN THE BMP SIGNALING CASCADE}

\section{Vascular Calcification}

Vascular calcification is a tightly regulated process that results from the phenotypic plasticity of vascular cells. It has been observed in several pathologies, including atherosclerosis, chronic kidney disease, diabetes, and hypertension. ECs can undergo EndMT to form myofibroblast-like cells or they can differentiate into chondrocyte- and osteoblast-like cells. When this happens, the surrounding extracellular matrix can become mineralized. When subjected to high shear stress, ECs disassemble their primary cilium, which renders them more sensitive to shear-induced EndMT (Egorova et al. 2011; Tkachenko et al. 2013) and BMPinduced, Slug-dependent osteogenic differentiation (Sanchez-Duffhues et al. 2015). Increased BMP-2 and BMP-4 expression at atherosclerotic sites potentiates such calcification (Boström et al. 1993; Dhore et al. 2001), whereas pharmacological inhibitors of BMP signaling or the BMP antagonist MGP can reduce vascular inflammation and calcification (Cai et al. 2012). Indeed, MGP overexpression attenuates vascular calcification in $A p o E^{-/-}$mice (Boström et al. 2001; Yao et al. 2010), and treatment with the extracellular domain of ALK-3 $\left(\mathrm{ALK}_{\mathrm{ECD}}\right)$ or LDN-193189, a small BMPRI kinase inhibitor, reduces vascular inflammation and calcification in $\mathrm{Ldlr}^{-/}$mice (Derwall et al. 2012). Furthermore, oxidized-LDL (oxLDL) and BMP-6 synergistically promote osteogenic differentiation in ECs, providing a potential mechanism for the interactions between BMP signaling, oxidative stress, and inflammation in the induction of atherosclerosis-associated vascular calcification (Yung et al. 2015).

The vascular calcification process also requires an inflammatory response and a phenotypic transformation of VSMCs into osteogenic cells under chronic inflammatory conditions (New and Aikawa 2011). Activation of the BMP-2 pathway increases both valvular and vascular calcification (Nakagawa et al. 2010; Song et al. 2015). Tumor necrosis factor (TNF) $\alpha$ can induce vascular calcification both indirectly (Buendia et al. 2015) and directly. In a paracrine manner, TNF- $\alpha$ induces BMP-2 expression in ECs and stimulates the release of BMP-2-containing endothelial microparticles (EMPs) ( $\mathrm{Li}$ et al. 2010). Vascular injury may facilitate fusion of the EMPs with VSMCs and favor osteogenic transformation of VSMCs, thus promoting vascular calcification (Buendia et al. 2015). Furthermore, Smad6 ${ }^{-/-}$mice develop vascular and valvular calcification, suggesting that Smad6 plays a protective role in this process 
M.-J. Goumans et al.
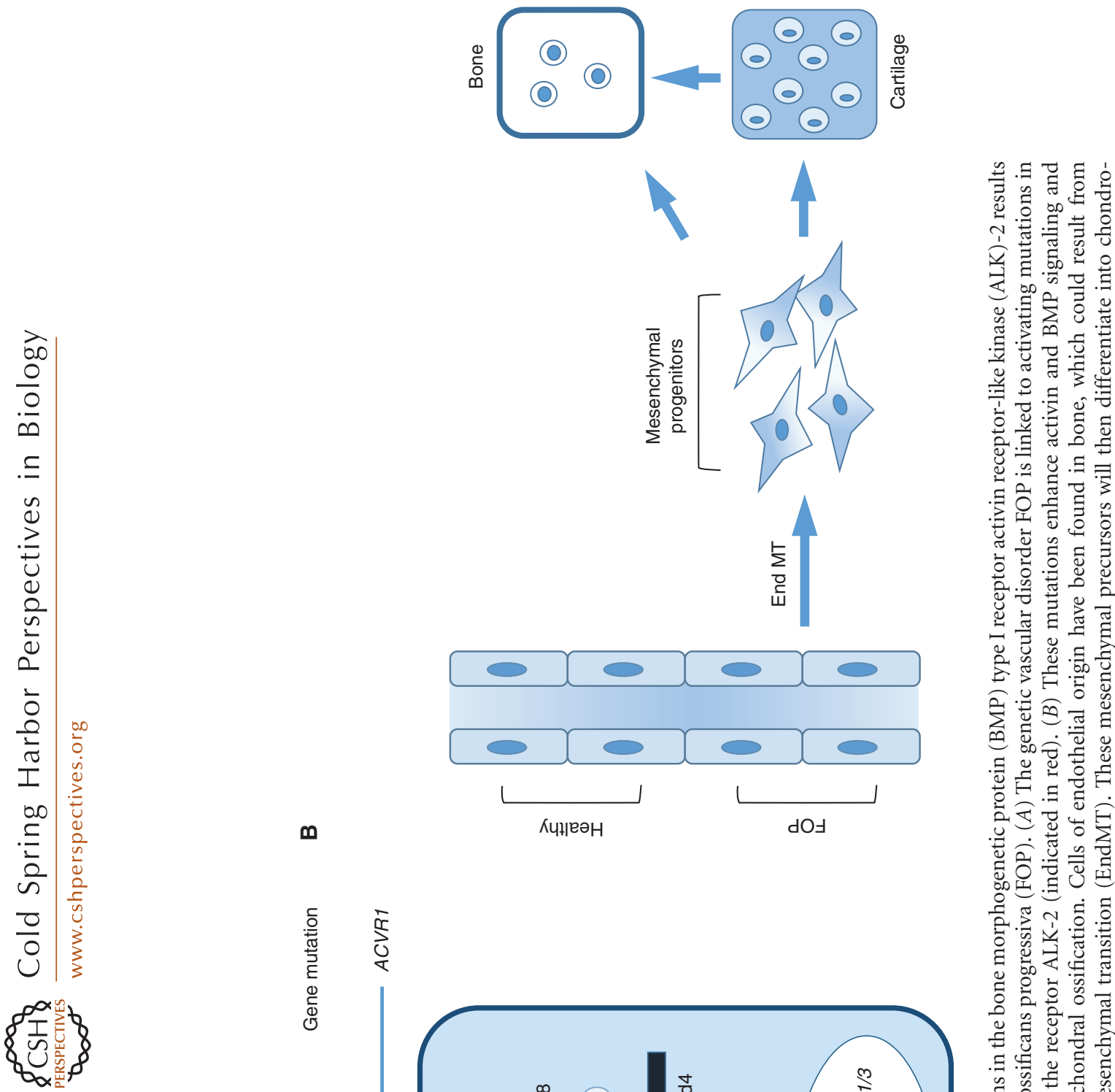

$\boldsymbol{m}$

구

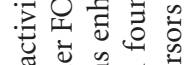

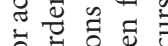

节.

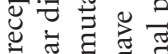

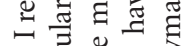

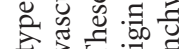

ลิ

ต

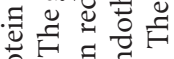

志可

ए

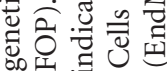

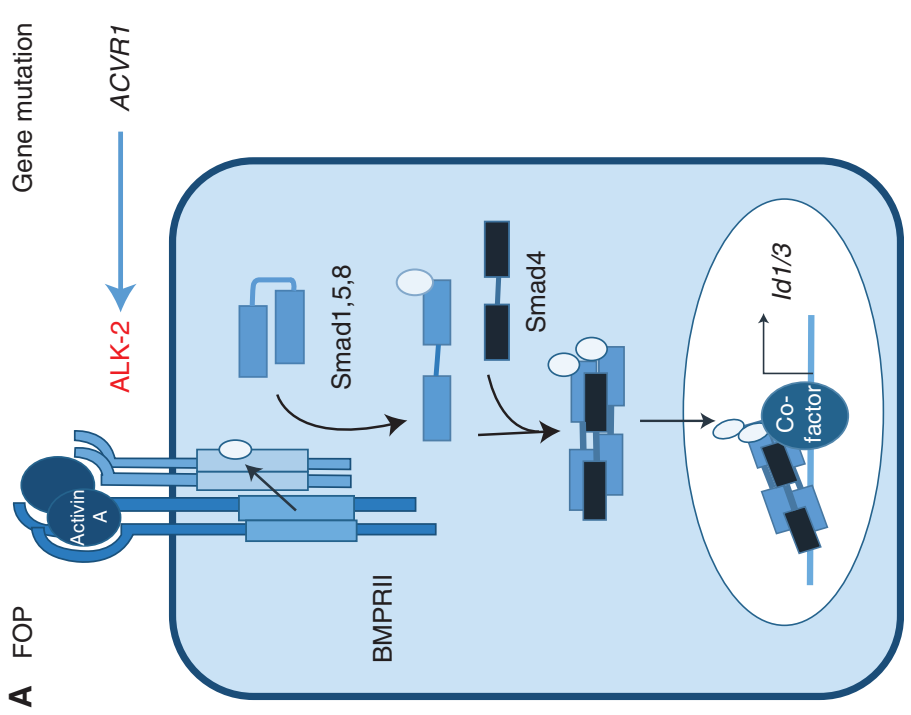

สำ

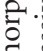

范光艺

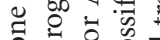

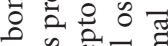

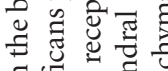

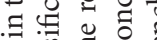

s.

웅

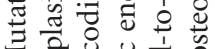

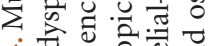

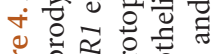

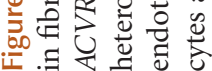


(Galvin et al. 2000). TNF- $\alpha$ also reduces Smad6 expression, highlighting a third potential mechanism for enhancing BMP-2 signaling levels in vascular cells ( $\mathrm{Li}$ et al. 2015b).

\section{Atherosclerosis}

Atherosclerosis is a chronic inflammatory response in the arterial wall, which is characterized by vascular plaque formation (Libby et al. 2011). Stable plaques contain more collagen and VSMCs, whereas unstable plaques possess a large lipid core covered with a thin fibrous cap containing macrophages. An unstable plaque is more likely to rupture, which can cause myocardial infarction or cerebrovascular accidents. Within atherosclerotic lesions, TGF- $\beta$ signaling components are detectable in ECs, VSMCs, myofibroblasts, dendritic cells, T cells, monocytes, and macrophages, and their expression is rapidly enhanced during vascular injury (Bobik et al. 1999; Frostegard et al. 1999; Kalinina et al. 2004; Bot et al. 2009). Atherosclerosis, plaque instability, and vascular calcification are also linked to altered BMP signaling, although no mutations in BMP signaling components have as yet been identified (Yao et al. 2010; Simoes Sato et al. 2014; Grgurevic et al. 2016).

BMPs are expressed in atherosclerotic plaques (Dhore et al. 2001) and colocalize with the valvular fibrosa (i.e., the calcified surface of the valve leaflets) (Mohler et al. 2001). Among patients with type 2 diabetes mellitus, plasma BMP-2 levels correlate positively with plaque burden and calcification (Zhang et al. 2015). Furthermore, increased BMP-2 levels exert pro-inflammatory and pro-atherogenic effects by stimulating oxidative stress and endothelial dysfunction as well as promoting plaque calcification by inducing an osteogenic phenotype in VSMCs (Li et al. 2008). Unexpectedly, BMPRII expression was found to be reduced in advanced human coronary atherosclerotic lesions, and Bmpr 2 heterozygosity in ApoE3 ${ }^{-/-}$ mice leads to robust inflammation and atherosclerosis (Kim et al. 2013). Bmpr2 deficiency increases monocyte adhesion owing to elevated ICAM-1 and VCAM-1 levels, whereas silencing of Acvrl1 decreases endothelial inflammation
(Kim et al. 2013). ApoE $E^{-/-} ; L d l r^{-/-}$mice that were fed a cholesterol diet showed significantly higher levels of soluble endoglin compared with $A p o E^{-/-} \mathrm{C} 57 \mathrm{BL} / 6 \mathrm{~J}$ mice and $A p o E^{-/-} ; \mathrm{Ldlr}^{-/-}$mice that were fed a chow diet (Strasky et al. 2011). Furthermore, soluble endoglin interferes with rolling and adhesion of leukocytes to ECs in culture (Walshe et al. 2009). Finally, BMP-7 combined with a partial left carotid artery ligation inhibits plaque formation in vivo in $A p o E^{-/-}$mice (Singla et al. 2016).

\section{Cerebral Cavernous Malformation}

Cerebral cavernous malformation (CCM) is a vascular dysplasia that is characterized by enlarged and irregular capillaries, mainly localized within the brain (Fischer et al. 2013). The affected capillaries have abnormally thin and fragile walls that make them prone to leakage, resulting in cerebral hemorrhages. CCM occurs in both sporadic and familial forms. Loss-offunction mutations in KRIT1 (also known as CCM1), which encodes the cerebral cavernous malformations 1 protein CCM1, CCM2, or CCM3 account for $\sim 90 \%$ of all cases of familial CCM, resulting in weakened cell-to-cell junctions and increased leakage from vessels (Stahl et al. 2008). EndMT occurs in ECs of the lesions in both the familial (Akers et al. 2009) and sporadic forms (Bravi et al. 2016) of CCM, and EndMT in $\mathrm{Ccm}^{-/-}$ECs is mediated by KLF-4-dependent induction of BMP-6 expression (Maddaluno et al. 2013; Cuttano et al. 2016). Inhibitors of the TGF- $\beta$ or BMP pathways can partially reduce both the number and the size of vascular lesions in $\mathrm{Ccm}^{-/-}$mice (Maddaluno et al. 2013; Cuttano et al. 2016).

\section{Preeclampsia}

Preeclampsia (PE) is characterized by hypertension and proteinuria and is associated with maternal endothelial dysfunction. Soluble endoglin is increased in PE, and the level of soluble endoglin has been proposed as a biomarker for PE that may reflect the extent of endothelial dysfunction (Levine et al. 2006; Venkatesha et al. 2006; Rathouska et al. 2015). Injection of 
M.-J. Goumans et al.

soluble endoglin acts in concert with the soluble Flt1 ectodomain to induce severe PE (Venkatesha et al. 2006). Furthermore, a transgenic mouse model overexpressing human soluble endoglin developed a PE-like phenotype, including increased arterial pressure (ValbuenaDiez et al. 2012). When the levels of membranous endoglin are suppressed and replaced by soluble endoglin, adhesion between vascular ECs and mural cells is inhibited (Rossi et al. 2016), suggesting that endoglin plays a critical role in mural cell adhesion and differentiation.

\section{Arteriogenesis and Ischemic}

\section{Neovascularization}

Vasculogenesis and angiogenesis also play pivotal roles in various ischemic disorders in adults. Researchers are exploring several therapeutic approaches that use endothelial progenitor cells (EPCs) to promote reendothelialization of damaged vessels, and enhance neovascularization following ischemic diseases, such as heart and limb ischemia. BMP-9 administration enhances blood flow recovery in vivo in a mouse model of hindlimb ischemia (Kim et al. 2015). This is corroborated by laser Doppler perfusion imaging results showing a significant decrease in blood flow recovery in $\mathrm{Eng}^{+/-}$and Acvrl1 ${ }^{+/-}$ mice with hindlimb ischemia. Interestingly, compared with controls, collateral artery size is significantly reduced in $\mathrm{Eng}^{+/-}$mice, but not in Acvrl1 $^{+/-}$mice (Seghers et al. 2012). This suggests that endoglin contributes to both shearinduced collateral artery growth and ischemiainduced angiogenesis, whereas ALK-1 may only be involved in ischemia-induced angiogenesis.

\section{SECOND HIT IN HHT AND PAH DISEASE PROGRESSION}

Accumulating evidence suggests that haploinsufficiency of BMPRII, ENG, or ACVRL1 are insufficient for HHT or PAH development. Furthermore, although all cells carry the same mutations, the pathology is only seen at specific locations and in specific vascular beds. Finally, different patients with the same mutations, show different timing of onset and severity of the disease. Therefore, a second hit is required for disease onset and progression. Analyses of different animal models suggest that the second hit that triggers disease onset and progression may include genetic modifiers, angiogenesis (discussed above), inflammation, metabolic stress, and/or hypoxia. Here, we discuss these putative additional triggers in the context of BMP signaling.

\section{Genetic Modifiers}

As discussed above, the genetic background of an animal model determines the disease onset and severity of both HHT and PAH, highlighting the importance of (epi)genetic modifiers. Accordingly, the PTPN14 gene-encoding the protein tyrosine phosphatase, nonreceptor type 14 (PTPN14)-is identified as a modifier of pulmonary AVM incidence in HHT (Benzinou et al. 2012). Other weaker genetic associations have also been identified between ENG and EMILIN2, which encodes the extracellular matrix protein elastin microfibril interfacer 2 (Pawlikowska et al. 2005; Letteboer et al. 2015).

\section{BMPs and Inflammation in Vascular Disease}

Inflammation plays a fundamental role in the initiation and progression of many vascular disorders, including HHT and PAH. During inflammation, monocytes migrate to and infiltrate the injured tissue, where they differentiate into macrophages. Macrophages can be divided in two main types, pro-inflammatory M1 macrophages that enhance the inflammatory response by secreting factors that stimulate disease progression, such as TNF- $\alpha$ and monocyte chemoattractant protein (MCP)-1, and anti-inflammatory M2 macrophages that promote wound healing and tissue repair (Dutta and Nahrendorf 2014; Dingenouts et al. 2015).

BMPs play roles in macrophage differentiation and modulate the inflammatory response. BMP-2 and BMP-4, which can be produced by atherosclerotic VSMCs, promote BMPRII-dependent monocyte attraction leading to inflammation of the atherosclerotic lesion (Simoes Sato et al. 2014). BMP-6 can activate M1 mac- 
rophages, and stimulates IL-6 expression dependent on ALK-2, Smad1, and p38 MAPK (Lee et al. 2010). On the other hand, BMP-7 induces macrophage differentiation toward an M2 phenotype and stimulates the production of anti-inflammatory cytokines, such as IL-10, while reducing IL-6 expression in a Smad- and PI3K-dependent manner (Rocher and Singla 2013; Rocher et al. 2012). BMP-7 treatment of ApoE $\mathrm{E}^{-/-}$mice inhibits monocyte infiltration and reduces the production of pro-inflammatory cytokines (Singla et al. 2016).

Monocytes express low endoglin levels, which are up-regulated during differentiation into macrophages (Lastres et al. 1992; O'Connell et al. 1992). Endoglin is a key determinant for both monocyte migration and differentiation (van Laake et al. 2006). Indeed, Eng heterozygosity hampers the ability of monocytes both to respond to stromal cell-derived factor-1 (SDF1) and to migrate toward and invade damaged tissue (Post et al. 2010). Moreover, monocytes with perturbed endoglin levels show impaired macrophage differentiation (van Laake et al. 2006; Aristorena et al. 2014; Dingenouts et al. 2015; Ojeda-Fernandez et al. 2016). It is unknown which ligand causes this effect and how it influences the development of HHT.

Ubiquitous expression of a cytoplasmically truncated BMPRII receptor (BMPRII ${ }^{\text {delx } 4 /+}$ ), which acts as dominant-negative inhibitor of endogenous BMPRII, results in mild hypertension but a substantial increase in pulmonary inflammation, in mice at 8 weeks of age, suggesting that BMPRII has anti-inflammatory effects ( Talati et al. 2014). This effect appears to be unique to BMPRII, as silencing the expression of ActRIIA and ActRIIB does not induce an inflammatory phenotype (Kim et al. 2013). Furthermore, BMPRII ${ }^{\text {delx4}}$-expressing macrophages show an M1 phenotype, with increased transcription factor NF- $\mathrm{B}$ activation and enhanced IL-6 secretion (Talati et al. 2014). Conditioned medium of the activated macrophages stimulates SMC migration, which is dependent on the BMP type I receptor. Finally, chronic lipopolysaccharide administration to Bmpr2 $2^{+/-}$ mice induces an exacerbated inflammatory response and pulmonary hypertension develop- ment with elevated IL-6 levels in the lungs and circulation (Soon et al. 2015). Inflammation has also been proposed to be a trigger for HHT, because $\mathrm{Eng}^{+/-}$mice with blepharitis have more pronounced bleeding lesions (Torsney et al. 2003). Lipopolysaccharide was also shown to trigger the formation of skin AVMs (Han et al. 2014).

\section{BMPs and Metabolism}

Even though ECs are in close proximity to oxygenated blood, they primarily rely on glycolysis rather than oxidative metabolism for the production of ATP (Goveia et al. 2014). Under physiological conditions, ECs produce $>80 \%$ of their ATP by converting glucose into lactate, and $<1 \%$ of glucose-derived pyruvate enters the mitochondria for oxidative metabolism through the tricarboxylic acid (TCA) cycle. The switch from a quiescent to an angiogenic phenotype is mediated by alterations of EC energy metabolism. Although such adaptations were first described in tumor angiogenesis, emerging evidence suggest that similar metabolic abnormalities characterize PAH. Metabolic features of ECs from PAH patients include high aerobic glycolysis, low oxidative metabolism, up-regulation of the pentose phosphate pathway, and increases in the nucleotide salvage and polyamine biosynthesis pathways (Fessel et al. 2012). ECs isolated from mice with ECspecific Bmpr2 inactivation show similarly increased expression of phosphoglycerate kinase (PGK) 1 (Majka et al. 2011). The similarities between the metabolic adaptations in $\mathrm{PAH}$ and the metabolic profile of angiogenic ECs could represent an opportunity for therapeutically targeting of EC metabolism in PAH by pharmacological inhibition of the glycolytic enzyme 6-phosphofructo-2-kinase/fructose-2,6biphosphatase isoform 3 (PFKFB3), for example, by using 3-(3-pyridinyl)-1-(4-pyridinyl)2-propen-1-one (3PO) (Clem et al. 2008).

\section{BMP and Hypoxia}

Hypoxia causes oxidative stress by increasing mitochondrial superoxide production. Both 
M.-J. Goumans et al.

BMPRII and endoglin levels are affected by hypoxia indicating that oxidative stress and metabolic dysfunction play direct pathogenic roles in HHT and PAH. Hypoxia increases endoglin expression in ECs in cell culture and infarcted murine hearts in vivo (van Laake et al. 2006). In hypoxic ECs, increased endoglin expression promotes expression of ALK-1 but not ALK-5 (Tian et al. 2010). Pulmonary endothelial expression of BMP-2 or BMP-4, but not BMP-5, BMP-6 or BMP-7, is increased following exposure to hypoxia (Frank et al. 2005). In mice heterozygous for Bmp4 $\left(B m p 4^{\mathrm{LacZ} /+}\right)$, loss of hypoxia-induced BMP-4 expression is associated with decreased pulmonary vascular remodeling and VSMC proliferation, and reduced PH (Anderson et al. 2010). BMP-9 signaling through BMPRII, ALK-1, and the transcription factor Id 1 protects ECs from hypoxia-induced apoptosis partly by inducing expression of the anti-apoptotic protein crystallin- $\alpha \mathrm{B}$ (CRYAB) (Ciumas et al. 2013). Hypoxia induces BMPRII down-regulation, and concomitantly reduces Smad1 and Smad5 phosphorylation and Id1 expression in pulmonary artery SMCs (Takahashi et al. 2006; Maruyama et al. 2016). Hypoxiainduced HIF- $1 \alpha$ activates the expression of miR-322, which in turn inhibits expression of $A L K 3$ and SMAD5 in pulmonary artery smooth muscle cells (PASMCs,) promoting hypoxiainduced PASMC proliferation and migration (Zeng et al. 2015). Moreover, hypoxia represses the expression of BMPER, resulting in enhanced BMP signaling and revascularization of the hypoxic retina (Moreno-Miralles et al. 2011). Together, these findings suggest that hypoxia modulates BMP signaling and may, therefore, be an interesting target for $\mathrm{HHT}$ and $\mathrm{PAH}$ treatment.

\section{BMP Signaling Goes Vascular}

Unbalanced BMP signaling is involved in several human vascular diseases, caused directly by mutations in BMP signaling components or indirectly by alteration of signaling levels. Together with evidence from numerous genetic animal models, these genetic correlations provide clear support for the view that BMP signaling plays a crucial role in vascular remodeling. BMPs exert potent effects on all blood and lymphatic cell lineages, affecting the capacity of ECs to migrate, proliferate, and form basic tubular structures. BMPs also help determine the fates of the surrounding pericytes, VSMCs, and adventitial cells that contribute to vessel structural integrity and function. BMP inhibition may be useful in the treatment of vascular disorders, such as CCM, vascular calcification and atherosclerosis, whereas BMP stimulation could be an effective treatment for HHT, PE, and PAH. Current knowledge suggests that BMP-9 and BMP-10, which share $65 \%$ amino acid sequence identity, are the most important BMP ligands in vascular development. This is supported by their binding with high affinity to BMPRII, ALK-1, and endoglin, which are expressed at relatively high levels by ECs and VSMCs, and their presence in blood (David et al. 2008). BMP-4 and BMP-6 also exist in serum, supporting their potential role in vascular development (Herrera and Inman 2009; Vukicevic and Grgurevic 2009), which is also supported by their involvement in vascular dysfunction like shear-mediated vascular remodeling and CCM. Furthermore, BMP-2, in particular in zebrafish (Wakayama et al. 2015), is gaining importance in vascular biology, including also in flow-mediated vascular calcification.

BMP-9 is produced by the liver (Miller et al. 2000; Bidart et al. 2012) and BMP-10 is produced in the heart, chiefly by the right atrium in adults (Neuhaus et al. 1999). The physiological levels of BMP-9 and BMP-10 are similar $(0.5-15 \mathrm{ng} / \mathrm{ml})$ in both human and mouse serum (David et al. 2007, 2008; Souza et al. 2008; Chen et al. 2013; Kienast et al. 2016). BMP-9 is considered as the main bioactive form in adult circulation, and indeed most BMP-Smad reporter activity is inhibited by a neutralizing anti-BMP-9 antibody (David et al. 2007; Ricard et al. 2012; Chen et al. 2013), and plasma from $B m p 9^{-1-}$ mice cannot activate this reporter (Ricard et al. 2012).

In vivo data clearly indicate that BMP-9 and BMP-10 signaling play major roles in vascular remodeling through BMPRII and ALK-1 (Ricard et al. 2012; Chen et al. 2013). However, 
the precise cellular mechanisms and molecular responses induced by these ligands in ECs and VSMCs remain incompletely understood. One possible explanation for contradictory findings is that context-specific mechanisms may be at play (David et al. 2009; Suzuki et al. 2010; Tillet and Bailly 2014).

One major difference between HHT and $\mathrm{PAH}$ is that they involve mutations in different types of receptors. Although HHT is linked to mutations in genes encoding the type I receptor, ACVRL1, or the coreceptor, ENG, PAH correlates with mutations of the type II receptor $B M P R 2$, although in few cases mutations in ACVRL1 have also been found. This raises the question as to whether the etiologies of these diseases can be explained by differences in ligand binding or downstream Smad-dependent or -independent signaling pathways. Another interesting point is that the type II receptor ActRIIA or ActRIIB cannot rescue BMPRII deficiency. Also, unlike ALK-1 and endoglin, which are primarily expressed in ECs, BMPRII is highly expressed in both ECs and VSMCs and, thus, is likely to directly influence EC and VSMC function.

It remains unclear as to how and why a disease that is caused by a mutation in a gene expressed widely throughout different vascular beds manifests primarily in only a few organs (e.g., the lung, brain, gastrointestinal tract, and liver). Vascular bed-specific endothelial effects of BMP-4 have been observed. BMP-4 exerts pro-oxidant, prohypertensive, and pro-inflammatory effects only in the systemic circulation, whereas pulmonary arteries are protected from these adverse effects of BMP-4 (Csiszar et al. 2008). Moreover, differences in shear stress and responses in different vascular beds likely contribute in the selective development of defects. The expression levels of various BMP receptors and attenuators at the cell surface, as well as the ligand availability in various vascular beds, likely contribute to the greater sensitivity of some vascular beds to mutations and phenotypic outcomes. A change in receptor availability may also alter the composition of preformed receptor complexes, such that BMPs might bind to different type I and type II receptors, thereby influencing the ratio between Smad-dependent and Smad-independent cascades (Hassel et al. 2003). In addition, some mutant receptors may become activated by uncommon ligands, as shown for activin binding to the mutant ALK-2 in FOP (Hatsell et al. 2015). Improving our understanding of how receptor complex localization and composition are disturbed in diseased ECs and VSMCs in different vascular beds may help explain why some tissues are more prone to develop vascular lesions than others.

The specific endothelial expression of ALK1 and endoglin and their roles in vessel network formation has led to the hypothesis that targeting ALK-1 or endoglin could be a new therapeutic approach to regulate tumor angiogenesis and lymphangiogenesis. Thus, recent strategies for cancer treatment have focused on simultaneous inhibition of VEGF and ALK-1 or endoglin (Bhatt and Atkins 2014; Gupta et al. 2015). A neutralizing ALK-1 antibody (Necchi et al. 2014), or the ALK1-Fc (Wang et al. 2016b) or endoglin-Fc ligand traps (Gordon et al. 2014), combined with a VEGF inhibitor or chemotherapy have been reported to inhibit tumor growth. Although these trials are encouraging, the highly context-dependent effects of ALK-1 and endoglin in controlling vascular function warrant further research to prevent unwanted side-effects of these approaches.

\section{CONCLUSION}

Genetic vascular diseases have revealed major roles of BMPs in vascular development and dysfunction. Unraveling their functions has enabled the development of new potential therapeutics for several vascular-related pathologies such as PAH and FOP. In the future, the development of selective small molecules modifiers of BMP signaling will be an important challenge and should lead to new therapeutic opportunities.

\section{ACKNOWLEDGMENTS}

We apologize to those whose work was not cited owing to lack of space. We thank David Baker for valuable comments on our manuscript and 
M.-J. Goumans et al.

Drs. J.J. Mager, A. Hosman, and E. Nossent for the images of HHT and PAH pathologies. Work in the laboratory of S.B. is funded by the INSERM, CEA, University of Grenoble Alpes (UGA), Association pour la Recherche sur le Cancer (ARC), the Ligue Contre le Cancer de la Loire et de la Savoie, and the Association Maladie de Rendu-Osler (AMRO). A.Z.'s work is supported by FWO G0542N13 and C12/16/ 023. Work in the M.-J.G. laboratory is supported by the Netherlands CardioVascular Research Initiative: an initiative with support of the Dutch Heart Foundation, Dutch Federation of University Medical Centers, the Netherlands Organisation for Health Research and Development, and the Royal Netherlands Academy of Sciences (CVON-PHAEDRA CVON2012-08 and CVON-RECONNECT CVON 2014-11), and NHS-BAV. The P.t.D. laboratory is supported by Cancer Genomics Centre Netherlands and the Netherlands CardioVascular Research Initiative: the Dutch Heart Foundation, Dutch Federation of University Medical Centers, the Netherlands Organisation for Health Research and Development, and the Royal Netherlands Academy of Sciences CVON-PHAEDRA CVON2012-08.

\section{REFERENCES}

${ }^{*}$ Reference is also in this subject collection.

Akers AL, Johnson E, Steinberg GK, Zabramski JM, Marchuk DA. 2009. Biallelic somatic and germline mutations in cerebral cavernous malformations (CCMs): Evidence for a two-hit mechanism of CCM pathogenesis. Hum Mol Genet 18: 919-930.

Alt A, Miguel-Romero L, Donderis J, Aristorena M, Blanco FJ, Round A, Rubio V, Bernabéu C, Marina A. 2012. Structural and functional insights into endoglin ligand recognition and binding. PLoS ONE 7: e29948.

Anderson L, Lowery JW, Frank DB, Novitskaya T, Jones M, Mortlock DP, Chandler RL, de Caestecker MP. 2010. Bmp2 and Bmp4 exert opposing effects in hypoxic pulmonary hypertension. Am J Physiol Regul Integr Comp Physiol 298: R833-842.

Aranguren XL, Beerens M, Coppiello G, Wiese C, Vandersmissen I, Lo Nigro A, Verfaillie CM, Gessler M, Luttun A. 2013. COUP-TFII orchestrates venous and lymphatic endothelial identity by homo- or hetero-dimerisation with PROX1. J Cell Sci 126: 1164-1175.

Aristorena M, Blanco FJ, de Las Casas-Engel M, Ojeda-Fernandez L, Gallardo-Vara E, Corbí A, Botella LM, Bernabéu C. 2014. Expression of endoglin isoforms in the my- eloid lineage and their role during aging and macrophage polarization. J Cell Sci 127: 2723-2735.

Arthur HM, Ure J, Smith AJ, Renforth G, Wilson DI, Torsney E, Charlton R, Parums DV, Jowett T, Marchuk DA, et al. 2000. Endoglin, an ancillary TGF- $\beta$ receptor, is required for extraembryonic angiogenesis and plays a key role in heart development. Dev Biol 217: 42-53.

Baeyens N, Larrivee B, Ola R, Hayward-Piatkowskyi B, Dubrac A, Huang B, Ross TD, Coon BG, Min E, Tsarfati M, et al. 2016. Defective fluid shear stress mechanotransduction mediates hereditary hemorrhagic telangiectasia. J Cell Biol 214: 807-816.

Benn A, Bredow C, Casanova I, Vukicevic S, Knaus P. 2016. VE-cadherin facilitates BMP-induced endothelial cell permeability and signaling. J Cell Sci 129: 206-218.

Benzinou M, Clermont FF, Letteboer TG, Kim JH, Espejel S, Harradine KA, Arbelaez J, Luu MT, Roy R, Quigley D, et al. 2012. Mouse and human strategies identify PTPN14 as a modifier of angiogenesis and hereditary haemorrhagic telangiectasia. Nat Commun 3: 616.

Beppu H, Ichinose F, Kawai N, Jones RC, Yu PB, Zapol WM, Miyazono K, Li E, Bloch KD. 2004. BMPR-II heterozygous mice have mild pulmonary hypertension and an impaired pulmonary vascular remodeling response to prolonged hypoxia. Am J Physiol Lung Cell Mol Physiol 287: L1241-L1247.

Bhatt RS, Atkins MB. 2014. Molecular pathways: Can activin-like kinase pathway inhibition enhance the limited efficacy of VEGF inhibitors? Clin Cancer Res 20: 28382845.

Bidart M, Ricard N, Levet S, Samson M, Mallet C, David L, Subileau M, Tillet E, Feige JJ, Bailly S. 2012. BMP9 is produced by hepatocytes and circulates mainly in an active mature form complexed to its prodomain. Cell $\mathrm{Mol}$ Life Sci 69: 313-324.

Blanco FJ, Santibanez JF, Guerrero-Esteo M, Langa C, Vary CP, Bernabéu C. 2005. Interaction and functional interplay between endoglin and ALK-1, two components of the endothelial transforming growth factor- $\beta$ receptor complex. J Cell Physiol 204: 574-584.

Bobik A, Agrotis A, Kanellakis P, Dilley R, Krushinsky A, Smirnov V, Tararak E, Condron M, Kostolias G. 1999. Distinct patterns of transforming growth factor- $\beta$ isoform and receptor expression in human atherosclerotic lesions. Colocalization implicates TGF- $\beta$ in fibrofatty lesion development. Circulation 99: 2883-2891.

Boström K, Watson KE, Horn S, Wortham C, Herman IM, Demer LL. 1993. Bone morphogenetic protein expression in human atherosclerotic lesions. J Clin Invest 91: 1800-1809.

Boström K, Tsao D, Shen S, Wang Y, Demer LL. 2001. Matrix GLA protein modulates differentiation induced by bone morphogenetic protein-2 in C3H10T1/2 cells. J Biol Chem 276: 14044-14052.

Bot PT, Hoefer IE, Sluijter JP, van Vliet P, Smits AM, Lebrin F, Moll F, de Vries JP, Doevendans P, Piek JJ, et al. 2009. Increased expression of the transforming growth factor- $\beta$ signaling pathway, endoglin, and early growth response-1 in stable plaques. Stroke 40: 439-447.

Bourdeau A, Dumont DJ, Letarte M. 1999. A murine model of hereditary hemorrhagic telangiectasia. J Clin Invest 104: $1343-1351$. 
Bourdeau A, Faughnan ME, Letarte M. 2000. Endoglin-deficient mice, a unique model to study hereditary hemorrhagic telangiectasia. Trends Cardiovasc Med 10: 279285.

Bourdeau A, Faughnan ME, McDonald ML, Paterson AD, Wanless IR, Letarte M. 2001. Potential role of modifier genes influencing transforming growth factor- $\beta 1$ levels in the development of vascular defects in endoglin heterozygous mice with hereditary hemorrhagic telangiectasia. Am J Pathol 158: 2011-2020.

Bragdon B, Moseychuk O, Saldanha S, King D, Julian J, Nohe A. 2011. Bone morphogenetic proteins: A critical review. Cell Signal 23: 609-620.

Bravi L, Malinverno M, Pisati F, Rudini N, Cuttano R, Pallini R, Martini M, Larocca LM, Locatelli M, Levi V, et al. 2016. Endothelial cells lining sporadic cerebral cavernous malformation cavernomas undergo endothelial-to-mesenchymal transition. Stroke 47: 886-890.

Buendia P, Montes de Oca A, Madueno JA, Merino A, Martin-Malo A, Aljama P, Ramirez R, Rodriguez M, Carracedo J. 2015. Endothelial microparticles mediate inflammation-induced vascular calcification. FASEB J 29: 173181.

Cai J, Pardali E, Sanchez-Duffhues G, ten Dijke P. 2012. BMP signaling in vascular diseases. FEBS Lett 586: 1993-2002.

Carmeliet P, Jain RK. 2011. Molecular mechanisms and clinical applications of angiogenesis. Nature 473: 298 307.

Carvalho RL, Jonker L, Goumans MJ, Larsson J, Bouwman P, Karlsson S, ten Dijke P, Arthur HM, Mummery CL. 2004. Defective paracrine signalling by TGF $\beta$ in yolk sac vasculature of endoglin mutant mice: A paradigm for hereditary haemorrhagic telangiectasia. Development 131: 6237-6247.

Castonguay R, Werner ED, Matthews RG, Presman E, Mulivor AW, Solban N, Sako D, Pearsall RS, Underwood KW, Seehra J, et al. 2011. Soluble endoglin specifically binds bone morphogenetic proteins 9 and 10 via its orphan domain, inhibits blood vessel formation, and suppresses tumor growth. J Biol Chem 286: 30034-30046.

Chan MC, Nguyen PH, Davis BN, Ohoka N, Hayashi H, Du K, Lagna G, Hata A. 2007. A novel regulatory mechanism of the bone morphogenetic protein (BMP) signaling pathway involving the carboxyl-terminal tail domain of BMP type II receptor. Mol Cell Biol 27: 5776-5789.

* Chang C. 2016. Agonists and antagonists of TGF- $\beta$ family ligands. Cold Spring Harb Perspect Biol 8: a021923.

Chang H, Huylebroeck D, Verschueren K, Guo Q, Matzuk MM, Zwijsen A. 1999. Smad5 knockout mice die at midgestation due to multiple embryonic and extraembryonic defects. Development 126: 1631-1642.

Chen H, Shi S, Acosta L, Li W, Lu J, Bao S, Chen Z, Yang Z, Schneider MD, Chien KR, et al. 2004. BMP10 is essential for maintaining cardiac growth during murine cardiogenesis. Development 131: 2219-2231.

Chen H, Brady Ridgway J, Sai T, Lai J, Warming S, Chen H, Roose-Girma M, Zhang G, Shou W, Yan M. 2013. Context-dependent signaling defines roles of BMP9 and BMP10 in embryonic and postnatal development. Proc Natl Acad Sci 110: 11887-11892.

Choi EJ, Walker EJ, Shen F, Oh SP, Arthur HM, Young WL, Su H. 2012. Minimal homozygous endothelial deletion of Eng with VEGF stimulation is sufficient to cause cerebrovascular dysplasia in the adult mouse. Cerebrovasc Dis 33: $540-547$.

Choi EJ, Kim YH, Choe SW, Tak YG, Garrido-Martin EM, Chang M, Lee YJ, Oh SP. 2013. Enhanced responses to angiogenic cues underlie the pathogenesis of hereditary hemorrhagic telangiectasia 2. PLoS ONE 8: e63138.

Choi EJ, Chen W, Jun K, Arthur HM, Young WL, Su H. 2014. Novel brain arteriovenous malformation mouse models for type 1 hereditary hemorrhagic telangiectasia. PLoS ONE 9: e88511.

Ciumas M, Eyries M, Poirier O, Maugenre S, Dierick F, Gambaryan N, Montagne K, Nadaud S, Soubrier F. 2013. Bone morphogenetic proteins protect pulmonary microvascular endothelial cells from apoptosis by upregulating $\alpha$-B-crystallin. Arterioscler Thromb Vasc Biol 33: $2577-2584$.

Clem B, Telang S, Clem A, Yalcin A, Meier J, Simmons A, Rasku MA, Arumugam S, Dean WL, Eaton J, et al. 2008. Small-molecule inhibition of 6-phosphofructo-2-kinase activity suppresses glycolytic flux and tumor growth. $\mathrm{Mol}$ Cancer Ther 7: 110-120.

Corradini E, Babitt JL, Lin HY. 2009. The RGM/DRAGON family of BMP co-receptors. Cytokine Growth Factor Rev 20: $389-398$.

Coso S, Bovay E, Petrova TV. 2014. Pressing the right buttons: Signaling in lymphangiogenesis. Blood 123: $2614-$ 2624.

Csiszar A, Labinskyy N, Jo H, Ballabh P, Ungvari Z. 2008. Differential proinflammatory and prooxidant effects of bone morphogenetic protein-4 in coronary and pulmonary arterial endothelial cells. Am J Physiol Heart Circ Physiol 295: H569-H577.

Cuttano R, Rudini N, Bravi L, Corada M, Giampietro C, Papa E, Morini MF, Maddaluno L, Baeyens N, Adams $\mathrm{RH}$, et al. 2016. KLF4 is a key determinant in the development and progression of cerebral cavernous malformations. EMBO Mol Med 8: 6-24.

David L, Mallet C, Mazerbourg S, Feige JJ, Bailly S. 2007. Identification of BMP9 and BMP10 as functional activators of the orphan activin receptor-like kinase 1 (ALK1) in endothelial cells. Blood 109: 1953-1961.

David L, Mallet C, Keramidas M, Lamande N, Gasc JM, Dupuis-Girod S, Plauchu H, Feige JJ, Bailly S. 2008. Bone morphogenetic protein-9 is a circulating vascular quiescence factor. Circ Res 102: 914-922.

David L, Feige JJ, Bailly S. 2009. Emerging role of bone morphogenetic proteins in angiogenesis. Cytokine Growth Factor Rev 20: 203-212.

Deng Z, Morse JH, Slager SL, Cuervo N, Moore KJ, Venetos G, Kalachikov S, Cayanis E, Fischer SG, Barst RJ, et al. 2000. Familial primary pulmonary hypertension (gene $P P H 1)$ is caused by mutations in the bone morphogenetic protein receptor-II gene. Am J Hum Genet 67: 737744.

Derwall M, Malhotra R, Lai CS, Beppu Y, Aikawa E, Seehra JS, Zapol WM, Bloch KD, Yu PB. 2012. Inhibition of bone morphogenetic protein signaling reduces vascular calcification and atherosclerosis. Arterioscler Thromb Vasc Biol 32: 613-622.

De Smet F, Segura I, De Bock K, Hohensinner PJ, Carmeliet P. 2009. Mechanisms of vessel branching: Filopodia on 


\section{M.-J. Goumans et al.}

endothelial tip cells lead the way. Arterioscler Thromb Vasc Biol 29: 639-649.

Dhore CR, Cleutjens JP, Lutgens E, Cleutjens KB, Geusens PP, Kitslaar PJ, Tordoir JH, Spronk HM, Vermeer C, Daemen MJ. 2001. Differential expression of bone matrix regulatory proteins in human atherosclerotic plaques. Arterioscler Thromb Vasc Biol 21: 1998-2003.

Dickinson MG, Bartelds B, Borgdorff MA, Berger RM. 2013. The role of disturbed blood flow in the development of pulmonary arterial hypertension: Lessons from preclinical animal models. Am J Physiol Lung Cell Mol Physiol 305: L1-L14.

Dingenouts CK, Goumans MJ, Bakker W. 2015. Mononuclear cells and vascular repair in HHT. Front Genet 6: 114

Dunworth WP, Cardona-Costa J, Bozkulak EC, Kim JD, Meadows S, Fischer JC, Wang Y, Cleaver O, Qyang Y, Ober EA, et al. 2014. Bone morphogenetic protein 2 signaling negatively modulates lymphatic development in vertebrate embryos. Circ Res 114: 56-66.

Dupuis-Girod S, Bailly S, Plauchu H. 2010. Hereditary hemorrhagic telangiectasia (HHT): From molecular biology to patient care. J Thromb Haemost 8: 1447-1456.

Dupuis-Girod S, Ginon I, Saurin JC, Marion D, Guillot E, Decullier E, Roux A, Carette MF, Gilbert-Dussardier B, Hatron PY, et al. 2012. Bevacizumab in patients with hereditary hemorrhagic telangiectasia and severe hepatic vascular malformations and high cardiac output. JAMA 307: 948-955.

Dutta P, Nahrendorf M. 2014. Regulation and consequences of monocytosis. Immunol Rev 262: 167-178.

Dyer L, Lockyer P, Wu Y, Saha A, Cyr C, Moser M, Pi X, Patterson C. 2015. BMPER promotes epithelial-mesenchymal transition in the developing cardiac cushions. PLoS ONE 10: e0139209.

Ebisawa T, Fukuchi M, Murakami G, Chiba T, Tanaka K, Imamura T, Miyazono K. 2001. Smurf1 interacts with transforming growth factor- $\beta$ type I receptor through Smad7 and induces receptor degradation. J Biol Chem 276: $12477-12480$.

Egorova AD, Khedoe PP, Goumans MJ, Yoder BK, Nauli SM, ten Dijke P, Poelmann RE, Hierck BP. 2011. Lack of primary cilia primes shear-induced endothelial-to-mesenchymal transition. Circ Res 108: 1093-1101.

Eilken HM, Adams RH. 2010. Dynamics of endothelial cell behavior in sprouting angiogenesis. Curr Opin Cell Biol 22: 617-625.

Evans JD, Girerd B, Montani D, Wang XJ, Galie N, Austin ED, Elliott G, Asano K, Grunig E, Yan Y, et al. 2016. BMPR2 mutations and survival in pulmonary arterial hypertension: An individual participant data meta-analysis. Lancet Respir Med 4: 129-137.

Fessel JP, Loyd JE, Austin ED. 2011. The genetics of pulmonary arterial hypertension in the post-BMPR2 era. Pulm Circ 1: 305-319.

Fessel JP, Hamid R, Wittmann BM, Robinson LJ, Blackwell T, Tada Y, Tanabe N, Tatsumi K, Hemnes AR, West JD. 2012. Metabolomic analysis of bone morphogenetic protein receptor type 2 mutations in human pulmonary endothelium reveals widespread metabolic reprogramming. Pulm Circ 2: 201-213.
Fischer A, Zalvide J, Faurobert E, Albiges-Rizo C, TournierLasserve E. 2013. Cerebral cavernous malformations: From CCM genes to endothelial cell homeostasis. Trends Mol Med 19: 302-308.

Francois M, Caprini A, Hosking B, Orsenigo F, Wilhelm D, Browne C, Paavonen K, Karnezis T, Shayan R, Downes M, et al. 2008. Sox 18 induces development of the lymphatic vasculature in mice. Nature 456: 643-647.

Frank DB, Abtahi A, Yamaguchi DJ, Manning S, Shyr Y, Pozzi A, Baldwin HS, Johnson JE, de Caestecker MP. 2005. Bone morphogenetic protein 4 promotes pulmonary vascular remodeling in hypoxic pulmonary hypertension. Circ Res 97: 496-504.

Frostegard J, Ulfgren AK, Nyberg P, Hedin U, Swedenborg J, Andersson U, Hansson GK. 1999. Cytokine expression in advanced human atherosclerotic plaques: Dominance of pro-inflammatory (Th1) and macrophage-stimulating cytokines. Atherosclerosis 145: 33-43.

Fruttiger M. 2007. Development of the retinal vasculature. Angiogenesis 10: 77-88.

Gallardo-Vara E, Blanco FJ, Roque M, Friedman SL, Suzuki T, Botella LM, Bernabéu C. 2016. Transcription factor KLF6 upregulates expression of metalloprotease MMP14 and subsequent release of soluble endoglin during vascular injury. Angiogenesis 19: 155-171.

Gallea S, Lallemand F, Atfi A, Rawadi G, Ramez V, SpinellaJaegle S, Kawai S, Faucheu C, Huet L, Baron R, et al. 2001. Activation of mitogen-activated protein kinase cascades is involved in regulation of bone morphogenetic protein2-induced osteoblast differentiation in pluripotent C2C12 cells. Bone 28: 491-498.

Gallione CJ, Repetto GM, Legius E, Rustgi AK, Schelley SL, Tejpar S, Mitchell G, Drouin E, Westermann CJ, Marchuk DA. 2004. A combined syndrome of juvenile polyposis and hereditary haemorrhagic telangiectasia associated with mutations in MADH4 (SMAD4). Lancet 363: 852-859.

Galvin KM, Donovan MJ, Lynch CA, Meyer RI, Paul RJ, Lorenz JN, Fairchild-Huntress V, Dixon KL, Dunmore JH, Gimbrone MAJr, et al. 2000. A role for Smad6 in development and homeostasis of the cardiovascular system. Nat Genet 24: 171-174.

Gamell C, Osses N, Bartrons R, Ruckle T, Camps M, Rosa JL, Ventura F. 2008. BMP2 induction of actin cytoskeleton reorganization and cell migration requires PI3-kinase and Cdc42 activity. J Cell Sci 121: 3960-3970.

Garcia de Vinuesa A, Abdelilah-Seyfried S, Knaus P, Zwijsen A, Bailly S. 2016. BMP signaling in vascular biology and dysfunction. Cytokine Growth Factor Rev 27: 65-79.

Garrido-Martin EM, Nguyen HL, Cunningham TA, Choe SW, Jiang Z, Arthur HM, Lee YJ, Oh SP. 2014. Common and distinctive pathogenetic features of arteriovenous malformations in hereditary hemorrhagic telangiectasia 1 and hereditary hemorrhagic telangiectasia 2 animal models-Brief report. Arterioscler Thromb Vasc Biol 34: 2232-2236.

Gebala V, Collins R, Geudens I, Phng LK, Gerhardt H. 2016. Blood flow drives lumen formation by inverse membrane blebbing during angiogenesis in vivo. Nat Cell Biol 18: $443-450$.

Girerd B, Montani D, Coulet F, Sztrymf B, Yaici A, Jais X, Tregouet D, Reis A, Drouin-Garraud V, Fraisse A, et al. 
2010. Clinical outcomes of pulmonary arterial hypertension in patients carrying an ACVRL1 (ALK1) mutation. Am J Respir Crit Care Med 181: 851-861.

Gomez-Arroyo JG, Farkas L, Alhussaini AA, Farkas D, Kraskauskas D, Voelkel NF, Bogaard HJ. 2012. The monocrotaline model of pulmonary hypertension in perspective. Am J Physiol Lung Cell Mol Physiol 302: L363-L369.

Gordon MS, Robert F, Matei D, Mendelson DS, Goldman JW, Chiorean EG, Strother RM, Seon BK, Figg WD, Peer CJ, et al. 2014. An open-label phase Ib dose-escalation study of TRC105 (anti-endoglin antibody) with bevacizumab in patients with advanced cancer. Clin Cancer Res 20: $5918-5926$.

Goumans MJ, Mummery C. 2000. Functional analysis of the TGF- $\beta$ receptor/Smad pathway through gene ablation in mice. Int J Dev Biol 44: 253-265.

* Goumans MJ, ten Dijke P. 2017. TGF- $\beta$ signaling in control of cardiovascular function. Cold Spring Harb Perspect Biol doi: 10.1101/cshperspect.a022210.

Goveia J, Stapor P, Carmeliet P. 2014. Principles of targeting endothelial cell metabolism to treat angiogenesis and endothelial cell dysfunction in disease. EMBO Mol Med 6: $1105-1120$.

Gregory AL, Xu G, Sotov V, Letarte M. 2014. Review: the enigmatic role of endoglin in the placenta. Placenta 35: S93-S99.

Grgurevic L, Christensen GL, Schulz TJ, Vukicevic S. 2016. Bone morphogenetic proteins in inflammation, glucose homeostasis and adipose tissue energy metabolism. $C y$ tokine Growth Factor Rev 27: 105-118.

Guicheux J, Lemonnier J, Ghayor C, Suzuki A, Palmer G, Caverzasio J. 2003. Activation of p38 mitogen-activated protein kinase and c-Jun-NH2-terminal kinase by BMP2 and their implication in the stimulation of osteoblastic cell differentiation. J Bone Miner Res 18: 2060-2068.

Guignabert C, Tu L, Girerd B, Ricard N, Huertas A, Montani D, Humbert M. 2015. New molecular targets of pulmonary vascular remodeling in pulmonary arterial hypertension: Importance of endothelial communication. Chest 147: 529-537.

Guignabert C, Bailly S, Humbert M. 2016. Restoring BMPRII functions in pulmonary arterial hypertension: Opportunities, challenges and limitations. Expert Opin Ther Targets 21: 181-190.

Guillot N, Kollins D, Gilbert V, Xavier S, Chen J, Gentle M, Reddy A, Böttinger E, Jiang R, Rastaldi MP, et al. 2012. BAMBI regulates angiogenesis and endothelial homeostasis through modulation of alternative TGF- $\beta$ signaling. PLOS ONE 7: e39406.

Guo X, Wang XF. 2009. Signaling cross-talk between TGF$\beta /$ BMP and other pathways. Cell Res 19: 71-88.

Gupta S, Gill D, Pal SK, Agarwal N. 2015. Activin receptor inhibitors-Dalantercept. Curr Oncol Rep 17: 14.

Han C, Hong KH, Kim YH, Kim MJ, Song C, Kim MJ, Kim SJ, Raizada MK, Oh SP. 2013. SMAD1 deficiency in either endothelial or smooth muscle cells can predispose mice to pulmonary hypertension. Hypertension 61: 10441052.

Han C, Choe SW, Kim YH, Acharya AP, Keselowsky BG, Sorg BS, Lee YJ, Oh SP. 2014. VEGF neutralization can prevent and normalize arteriovenous malformations in an animal model for hereditary hemorrhagic telangiectasia 2. Angiogenesis 17: 823-830.

Hao Q, Zhu Y, Su H, Shen F, Yang GY, Kim H, Young WL. 2010. VEGF induces more severe cerebrovascular dysplasia in $\mathrm{Eng}^{+/-}$than in $A l k 1^{+/-}$mice. Transl Stroke Res 1: 197-201.

Harrison RE, Flanagan JA, Sankelo M, Abdalla SA, Rowell J, Machado RD, Elliott CG, Robbins IM, Olschewski H, McLaughlin V, et al. 2003. Molecular and functional analysis identifies ALK-1 as the predominant cause of pulmonary hypertension related to hereditary haemorrhagic telangiectasia. J Med Genet 40: 865-871.

Hassel S, Schmitt S, Hartung A, Roth M, Nohe A, Petersen N, Ehrlich M, Henis YI, Sebald W, Knaus P. 2003. Initiation of Smad-dependent and Smad-independent signaling via distinct BMP-receptor complexes. J Bone Joint Surg Am 85-A: 44-51.

Hassel S, Eichner A, Yakymovych M, Hellman U, Knaus P, Souchelnytskyi S. 2004. Proteins associated with type II bone morphogenetic protein receptor (BMPR-II) and identified by two-dimensional gel electrophoresis and mass spectrometry. Proteomics 4: 1346-1358.

Hata A, Lagna G, Massagué J, Hemmati-Brivanlou A. 1998. Smad6 inhibits BMP/Smad1 signaling by specifically competing with the Smad4 tumor suppressor. Genes Dev 12: 186-197.

Hatsell SJ, Idone V, Wolken DM, Huang L, Kim HJ, Wang L, Wen X, Nannuru KC, Jimenez J, Xie L, et al. 2015. $A C V R 1^{R 206 H}$ receptor mutation causes fibrodysplasia ossificans progressiva by imparting responsiveness to activin A. Sci Transl Med 7: 303ra137.

Hawinkels LJ, Kuiper P, Wiercinska E, Verspaget HW, Liu Z, Pardali E, Sier CF, ten Dijke P. 2010. Matrix metalloproteinase-14 (MT1-MMP)-mediated endoglin shedding inhibits tumor angiogenesis. Cancer Res 70: 4141-4150.

Heinke J, Juschkat M, Charlet A, Mnich L, Helbing T, Bode C, Patterson C, Moser M. 2013. Antagonism and synergy between extracellular BMP modulators Tsg and BMPER balance blood vessel formation. J Cell Sci 126: $3082-$ 3094.

Hernandez F, Huether R, Carter L, Johnston T, Thompson J, Gossage JR, Chao E, Elliott AM. 2015. Mutations in RASA1 and GDF2 identified in patients with clinical features of hereditary hemorrhagic telangiectasia. Hum Genome Var 2: 15040.

Herrera B, Inman GJ. 2009. A rapid and sensitive bioassay for the simultaneous measurement of multiple bone morphogenetic proteins. Identification and quantification of BMP4, BMP6 and BMP9 in bovine and human serum. BMC Cell Biol 10: 20.

* Hill CS. 2016. Transcriptional control by the SMADs. Cold Spring Harb Perspect Biol 8: a022079.

* Hinck AP, Mueller TD, Springer TA. 2016. Structural biology and evolution of the TGF- $\beta$ family. Cold Spring Harb Perspect Biol 8: a022103.

Hong KH, Lee YJ, Lee E, Park SO, Han C, Beppu H, Li E, Raizada MK, Bloch KD, Oh SP. 2008. Genetic ablation of the Bmpr2 gene in pulmonary endothelium is sufficient to predispose to pulmonary arterial hypertension. Circulation 118: 722-730. 


\section{M.-J. Goumans et al.}

Huang Z, Wang D, Ihida-Stansbury K, Jones PL, Martin JF 2009. Defective pulmonary vascular remodeling in Smad8 mutant mice. Hum Mol Genet 18: 2791-2801.

Huse M, Chen YG, Massagué J, Kuriyan J. 1999. Crystal structure of the cytoplasmic domain of the type I TGF$\beta$ receptor in complex with FKBP12. Cell 96: 425-436.

Ikeya M, Kawada M, Kiyonari H, Sasai N, Nakao K, Furuta Y, Sasai Y. 2006. Essential pro-Bmp roles of crossveinless 2 in mouse organogenesis. Development 133: 4463-4473.

Ishisaki A, Yamato K, Hashimoto S, Nakao A, Tamaki K, Nonaka K, ten Dijke P, Sugino H, Nishihara T. 1999. Differential inhibition of Smad6 and Smad7 on bone morphogenetic protein- and activin-mediated growth arrest and apoptosis in B cells. J Biol Chem 274: 13637-13642.

Jadrich JL, O'Connor MB, Coucouvanis E. 2006. The TGF- $\beta$ activated kinase TAK1 regulates vascular development in vivo. Development 133: 1529-1541.

Jerkic M, Kabir MG, Davies A, Yu LX, McIntyre BA, Husain NW, Enomoto M, Sotov V, Husain M, Henkelman M, et al. 2011. Pulmonary hypertension in adult Alk1 heterozygous mice due to oxidative stress. Cardiovasc Res 92: 375-384.

Jiang B, Deng Y, Suen C, Taha M, Chaudhary KR, Courtman DW, Stewart DJ. 2016a. Marked strain-specific differences in the SU5416 rat model of severe pulmonary arterial hypertension. Am J Respir Cell Mol Biol 54: 461-468.

Jiang H, Salmon RM, Upton PD, Wei Z, Lawera A, Davenport AP, Morrell NW, Li W. 2016b. The prodomainbound form of bone morphogenetic protein 10 is biologically active on endothelial cells. J Biol Chem 291: 2954-2966.

Johnson DW, Berg JN, Baldwin MA, Gallione CJ, Marondel I, Yoon SJ, Stenzel TT, Speer M, Pericak-Vance MA, Diamond A, et al. 1996. Mutations in the activin receptorlike kinase 1 gene in hereditary haemorrhagic telangiectasia type 2. Nat Genet 13: 189-195.

Kalinina N, Agrotis A, Antropova Y, Ilyinskaya O, Smirnov V, Tararak E, Bobik A. 2004. Smad expression in human atherosclerotic lesions: Evidence for impaired TGF- $\beta$ / Smad signaling in smooth muscle cells of fibrofatty lesions. Arterioscler Thromb Vasc Biol 24: 1391-1396.

* Katagiri T, Watabe T. 2016. Bone morphogenetic proteins. Cold Spring Harb Perspect Biol 8: a021899.

Kavsak P, Rasmussen RK, Causing CG, Bonni S, Zhu H, Thomsen GH, Wrana JL. 2000. Smad7 binds to Smurf2 to form an E3 ubiquitin ligase that targets the TGF- $\beta$ receptor for degradation. Mol Cell 6: 1365-1375.

Kienast Y, Jucknischke U, Scheiblich S, Thier M, de Wouters M, Haas A, Lehmann C, Brand V, Bernicke D, Honold K, et al. 2016. Rapid activation of bone morphogenic protein 9 by receptor-mediated displacement of pro-domains. J Biol Chem 291: 3395-3410.

Kim JD, Kim J. 2014. Alk3/Alk3b and Smad5 mediate BMP signaling during lymphatic development in zebrafish Mol Cells 37: 270-274.

Kim CW, Song H, Kumar S, Nam D, Kwon HS, Chang KH, Son DJ, Kang DW, Brodie SA, Weiss D, et al. 2013. Antiinflammatory and antiatherogenic role of BMP receptor II in endothelial cells. Arterioscler Thromb Vasc Biol 33: $1350-1359$.
Kim J, Kim M, Jeong Y, Lee WB, Park H, Kwon JY, Kim YM, Hwang D, Kwon YG. 2015. BMP9 induces cord bloodderived endothelial progenitor cell differentiation and ischemic neovascularization via ALK1. Arterioscler Thromb Vasc Biol 35: 2020-2031.

Kirkbride KC, Townsend TA, Bruinsma MW, Barnett JV, Blobe GC. 2008. Bone morphogenetic proteins signal through the transforming growth factor- $\beta$ type III receptor. J Biol Chem 283: 7628-7637.

Korn C, Augustin HG. 2015. Mechanisms of vessel pruning and regression. Dev Cell 34: 5-17.

Lagendijk AK, Hogan BM. 2015. VE-cadherin in vascular development: A coordinator of cell signaling and tissue morphogenesis. Curr Top Dev Biol 112: 325-352.

Lane KB, Machado RD, Pauciulo MW, Thomson JR, Phillips JAIII, Loyd JE, Nichols WC, Trembath RC. 2000. Heterozygous germline mutations in BMPR2, encoding a TGF$\beta$ receptor, cause familial primary pulmonary hypertension. The International PPH Consortium. Nat Genet 26: 81-84.

Larrivee B, Prahst C, Gordon E, Del Toro R, Mathivet T, Duarte A, Simons M, Eichmann A. 2012. ALK1 signaling inhibits angiogenesis by cooperating with the Notch pathway. Dev Cell 22: 489-500.

Lastres P, Bellón T, Cabanas C, Sanchez-Madrid F, Acevedo A, Gougos A, Letarte M, Bernabéu C. 1992. Regulated expression on human macrophages of endoglin, an ArgGly-Asp-containing surface antigen. Eur J Immunol 22: 393-397.

Lawrie A. 2014. A report on the use of animal models and phenotyping methods in pulmonary hypertension research. Pulm Circ 4: 2-9.

Lebrin F, Goumans MJ, Jonker L, Carvalho RL, Valdimarsdottir G, Thorikay M, Mummery C, Arthur HM, ten Dijke P. 2004. Endoglin promotes endothelial cell proliferation and TGF- $\beta$ /ALK1 signal transduction. EMBO J 23: 4018-4028.

Lebrin F, Srun S, Raymond K, Martin S, van den Brink S, Freitas C, Breant C, Mathivet T, Larrivee B, Thomas JL, et al. 2010. Thalidomide stimulates vessel maturation and reduces epistaxis in individuals with hereditary hemorrhagic telangiectasia. Nat Med 16: 420-428.

Lee NY, Ray B, How T, Blobe GC. 2008. Endoglin promotes transforming growth factor- $\beta$-mediated Smad 1/5/8 signaling and inhibits endothelial cell migration through its association with GIPC. J Biol Chem 283: 32527-32533.

Lee GT, Kwon SJ, Lee JH, Jeon SS, Jang KT, Choi HY, Lee HM, Kim WJ, Kim SJ, Kim IY. 2010. Induction of interleukin- 6 expression by bone morphogenetic protein- 6 in macrophages requires both SMAD and p38 signaling pathways. J Biol Chem 285: 39401-39408.

Lee NY, Golzio C, Gatza CE, Sharma A, Katsanis N, Blobe GC. 2012. Endoglin regulates PI3-kinase/Akt trafficking and signaling to alter endothelial capillary stability during angiogenesis. Mol Biol Cell 23: 2412-2423.

Lesca G, Olivieri C, Burnichon N, Pagella F, Carette MF, Gilbert-Dussardier B, Goizet C, Roume J, Rabilloud M, Saurin JC, et al. 2007. Genotype-phenotype correlations in hereditary hemorrhagic telangiectasia: Data from the French-Italian HHT network. Genet Med 9: 14-22.

Letteboer TG, Mager JJ, Snijder RJ, Koeleman BP, Lindhout D, Ploos van Amstel JK, Westermann CJ. 2006. Geno- 
type-phenotype relationship in hereditary haemorrhagic telangiectasia. J Med Genet 43: 371-377.

Letteboer TG, Benzinou M, Merrick CB, Quigley DA, Zhau K, Kim IJ, To MD, Jablons DM, van Amstel JK, Westermann CJ, et al. 2015. Genetic variation in the functional $E N G$ allele inherited from the non-affected parent associates with presence of pulmonary arteriovenous malformation in hereditary hemorrhagic telangiectasia 1 (HHT1) and may influence expression of PTPN14. Front Genet 6: 67.

Levet S, Ciais D, Merdzhanova G, Mallet C, Zimmers TA, Lee SJ, Navarro FP, Texier I, Feige JJ, Bailly S, et al. 2013. Bone morphogenetic protein 9 (BMP9) controls lymphatic vessel maturation and valve formation. Blood 122: 598-607.

Levine RJ, Lam C, Qian C, Yu KF, Maynard SE, Sachs BP, Sibai BM, Epstein FH, Romero R, Thadhani R, et al. 2006. Soluble endoglin and other circulating antiangiogenic factors in preeclampsia. $N$ Engl J Med 355: 992-1005.

Li DY, Sorensen LK, Brooke BS, Urness LD, Davis EC, Taylor DG, Boak BB, Wendel DP. 1999. Defective angiogenesis in mice lacking endoglin. Science 284: 1534-1537.

Li X, Yang HY, Giachelli CM. 2008. BMP-2 promotes phosphate uptake, phenotypic modulation, and calcification of human vascular smooth muscle cells. Atherosclerosis 199: $271-277$.

Li Y, Messina C, Bendaoud M, Fine DH, Schreiner H, Tsiagbe VK. 2010. Adaptive immune response in osteoclastic bone resorption induced by orally administered Aggregatibacter actinomycetemcomitans in a rat model of periodontal disease. Mol Oral Microbiol 25: 275-292.

Li CJ, Madhu V, Balian G, Dighe AS, Cui Q. 2015a. Crosstalk between VEGF and BMP-6 pathways accelerates osteogenic differentiation of human adipose-derived stem cells. J Cell Physiol 230: 2671-2682.

Li X, Lim J, Lu J, Pedego TM, Demer L, Tintut Y. 2015b. Protective role of Smad6 in inflammation-induced valvular cell calcification. J Cell Biochem 116: 2354-2364.

Libby P, Ridker PM, Hansson GK. 2011. Progress and challenges in translating the biology of atherosclerosis. Nature 473: 317-325.

Long L, MacLean MR, Jeffery TK, Morecroft I, Yang X, Rudarakanchana N, Southwood M, James V, Trembath RC, Morrell NW. 2006. Serotonin increases susceptibility to pulmonary hypertension in BMPR2-deficient mice. Circ Res 98: 818-827.

Long L, Ormiston ML, Yang X, Southwood M, Graf S, Machado RD, Mueller M, Kinzel B, Yung LM, Wilkinson JM et al. 2015. Selective enhancement of endothelial BMPRII with BMP9 reverses pulmonary arterial hypertension. Nat Med 21: 777-785.

Luo W, Zhao X, Jin H, Tao L, Zhu J, Wang H, Hemmings BA, Yang Z. 2015. Akt1 signaling coordinates BMP signaling and $\beta$-catenin activity to regulate second heart field progenitor development. Development 142: 732-742.

Maarman G, Lecour S, Butrous G, Thienemann F, Sliwa K. 2013. A comprehensive review: The evolution of animal models in pulmonary hypertension research; are we there yet? Pulm Circ 3: 739-756.

Machado RD, Southgate L, Eichstaedt CA, Aldred MA, Austin ED, Best DH, Chung WK, Benjamin N, Elliott CG, Eyries M, et al. 2015. Pulmonary arterial hypertension: A current perspective on established and emerging molecular genetic defects. Hum Mutat 36: 1113-1127.

Maddaluno L, Rudini N, Cuttano R, Bravi L, Giampietro C, Corada M, Ferrarini L, Orsenigo F, Papa E, Boulday G, et al. 2013. EndMT contributes to the onset and progression of cerebral cavernous malformations. Nature 498: 492496.

Mahlawat P, Ilangovan U, Biswas T, Sun LZ, Hinck AP. 2012. Structure of the Alk1 extracellular domain and characterization of its bone morphogenetic protein (BMP) binding properties. Biochemistry 51: 6328-6341.

Mahmoud M, Allinson KR, Zhai Z, Oakenfull R, Ghandi P, Adams RH, Fruttiger M, Arthur HM. 2010. Pathogenesis of arteriovenous malformations in the absence of endoglin. Circ Res 106: 1425-1433.

Mair KM, Yang XD, Long L, White K, Wallace E, Ewart MA, Docherty CK, Morrell NW, MacLean MR. 2015. Sex affects bone morphogenetic protein type II receptor signaling in pulmonary artery smooth muscle cells. Am J Respir Crit Care Med 191: 693-703.

Majka S, Hagen M, Blackwell T, Harral J, Johnson JA, Gendron R, Paradis H, Crona D, Loyd JE, Nozik-Grayck E, et al. 2011. Physiologic and molecular consequences of endothelial Bmpr2 mutation. Respir Res 12: 84 .

Maruyama H, Dewachter C, Sakai S, Belhaj A, Rondelet B, Remmelink M, Vachiery JL, Naeije R, Dewachter L. 2016. Bosentan reverses the hypoxia-induced downregulation of the bone morphogenetic protein signaling in pulmonary artery smooth muscle cells. Life Sci 159: 111-115.

McAllister KA, Grogg KM, Johnson DW, Gallione CJ, Baldwin MA, Jackson CE, Helmbold EA, Markel DS, McKinnon WC, Murrell J, et al. 1994. Endoglin, a TGF- $\beta$ binding protein of endothelial cells, is the gene for hereditary haemorrhagic telangiectasia type 1. Nat Genet 8: 345351.

McDonald J, Wooderchak-Donahue W, VanSant Webb C, Whitehead K, Stevenson DA, Bayrak-Toydemir P. 2015. Hereditary hemorrhagic telangiectasia: Genetics and molecular diagnostics in a new era. Front Genet 6: 1.

Medici D, Shore EM, Lounev VY, Kaplan FS, Kalluri R, Olsen BR. 2010. Conversion of vascular endothelial cells into multipotent stem-like cells. Nat Med 16: 1400-1406.

Miller AF, Harvey SA, Thies RS, Olson MS. 2000. Bone morphogenetic protein-9. An autocrine/paracrine cytokine in the liver. J Biol Chem 275: 17937-17945.

* Miyazawa K, Miyazono K. 2016. Regulation of TGF- $\beta$ family signaling by inhibitory Smads. Cold Spring Harb Perspect Biol 9: a022095.

Miyazono K, Kamiya Y, Morikawa M. 2010. Bone morphogenetic protein receptors and signal transduction. J Biochem 147: $35-51$.

Mohler ERIII, Gannon F, Reynolds C, Zimmerman R, Keane MG, Kaplan FS. 2001. Bone formation and inflammation in cardiac valves. Circulation 103: 1522-1528.

Moreno-Miralles I, Ren R, Moser M, Hartnett ME, Patterson C. 2011. Bone morphogenetic protein endothelial cell precursor-derived regulator regulates retinal angiogenesis in vivo in a mouse model of oxygen-induced retinopathy. Arterioscler Thromb Vasc Biol 31: 22162222. 
M.-J. Goumans et al.

* Morikawa M, Derynck R, Miyazono K. 2016. TGF- $\beta$ and the TGF- $\beta$ family: Context-dependent roles in cell and tissue physiology. Cold Spring Harb Perspect Biol 8: a021873.

Morioka S, Inagaki M, Komatsu Y, Mishina Y, Matsumoto K, Ninomiya-Tsuji J. 2012. TAK1 kinase signaling regulates embryonic angiogenesis by modulating endothelial cell survival and migration. Blood 120: 3846-3857.

Morrell NW, Bloch DB, ten Dijke P, Goumans MJ, Hata A, Smith J, Yu PB, Bloch KD. 2016. Targeting BMP signalling in cardiovascular disease and anaemia. Nat Rev Cardiol 13: 106-120.

Moser M, Binder O, Wu Y, Aitsebaomo J, Ren R, Bode C, Bautch VL, Conlon FL, Patterson C. 2003. BMPER, a novel endothelial cell precursor-derived protein, antagonizes bone morphogenetic protein signaling and endothelial cell differentiation. Mol Cell Biol 23: 5664-5679.

Moya IM, Umans L, Maas E, Pereira PN, Beets K, Francis A, Sents W, Robertson EJ, Mummery CL, Huylebroeck D, et al. 2012. Stalk cell phenotype depends on integration of Notch and Smad1/5 signaling cascades. Dev Cell 22: 501-514.

Mueller TD, Nickel J. 2012. Promiscuity and specificity in BMP receptor activation. FEBS Lett 586: 1846-1859.

Murakami G, Watabe T, Takaoka K, Miyazono K, Imamura T. 2003. Cooperative inhibition of bone morphogenetic protein signaling by Smurf1 and inhibitory Smads. Mol Biol Cell 14: 2809-2817.

Nakagawa Y, Ikeda K, Akakabe Y, Koide M, Uraoka M, Yutaka KT, Kurimoto-Nakano R, Takahashi T, Matoba S, Yamada H, et al. 2010. Paracrine osteogenic signals via bone morphogenetic protein-2 accelerate the atherosclerotic intimal calcification in vivo. Arterioscler Thromb Vasc Biol 30: 1908-1915.

Necchi A, Giannatempo P, Mariani L, Fare E, Raggi D, Pennati M, Zaffaroni N, Crippa F, Marchiano A, Nicolai N, et al. 2014. PF-03446962, a fully-human monoclonal antibody against transforming growth-factor- $\beta$ (TGF- $\beta$ ) receptor ALK1, in pre-treated patients with urothelial cancer: An open label, single-group, phase 2 trial. Invest New Drugs 32: 555-560.

Neuhaus H, Rosen V, Thies RS. 1999. Heart specific expression of mouse BMP-10 a novel member of the TGF- $\beta$ superfamily. Mech Dev 80: 181-184.

New SE, Aikawa E. 2011. Cardiovascular calcification: An inflammatory disease. Circ J 75: 1305-1313.

Nicolls MR, Mizuno S, Taraseviciene-Stewart L, Farkas L, Drake JI, Al Husseini A, Gomez-Arroyo JG, Voelkel NF, Bogaard HJ. 2012. New models of pulmonary hypertension based on VEGF receptor blockade-induced endothelial cell apoptosis. Pulm Circ 2: 434-442.

Niessen K, Zhang G, Ridgway JB, Chen H, Yan M. 2010. ALK1 signaling regulates early postnatal lymphatic vessel development. Blood 115: 1654-1661.

O'Connell PJ, McKenzie A, Fisicaro N, Rockman SP, Pearse MJ, d'Apice AJ. 1992. Endoglin: A $180-\mathrm{kD}$ endothelial cell and macrophage restricted differentiation molecule. Clin Exp Immunol 90: 154-159.

Oh SP, Seki T, Goss KA, Imamura T, Yi Y, Donahoe PK, Li L, Miyazono K, ten Dijke P, Kim S, et al. 2000. Activin receptor-like kinase 1 modulates transforming growth factor- $\beta 1$ signaling in the regulation of angiogenesis. Proc Natl Acad Sci 97: 2626-2631.

Ojeda-Fernandez L, Recio-Poveda L, Aristorena M, Lastres P, Blanco FJ, Sanz-Rodriguez F, Gallardo-Vara E, de Las Casas-Engel M, Corbí A, Arthur HM, et al. 2016. Mice lacking endoglin in macrophages show an impaired immune response. PLoS Genet 12: e1005935.

Ola R, Dubrac A, Han J, Zhang F, Fang JS, Larrivee B, Lee M, Urarte AA, Kraehling JR, Genet G, et al. 2016. PI3 kinase inhibition improves vascular malformations in mouse models of hereditary haemorrhagic telangiectasia. Nat Commun 7: 13650.

Olsen OE, Wader KF, Misund K, Vatsveen TK, Ro TB, Mylin AK, Turesson I, Stordal BF, Moen SH, Standal T, et al. 2014. Bone morphogenetic protein-9 suppresses growth of myeloma cells by signaling through ALK2 but is inhibited by endoglin. Blood Cancer J 4: e196.

Onichtchouk D, Chen YG, Dosch R, Gawantka V, Delius H, Massagué J, Niehrs C. 1999. Silencing of TGF- $\beta$ signalling by the pseudoreceptor BAMBI. Nature 401: 480485.

Park SO, Lee YJ, Seki T, Hong KH, Fliess N, Jiang Z, Park A, Wu X, Kaartinen V, Roman BL, et al. 2008. ALK5- and TGFBR2-independent role of ALK1 in the pathogenesis of hereditary hemorrhagic telangiectasia type 2. Blood 111: 633-642.

Park SO, Wankhede M, Lee YJ, Choi EJ, Fliess N, Choe SW, Oh SH, Walter G, Raizada MK, Sorg BS, et al. 2009. Realtime imaging of de novo arteriovenous malformation in a mouse model of hereditary hemorrhagic telangiectasia. $J$ Clin Invest 119: 3487-3496.

Pawlikowska L, Tran MN, Achrol AS, Ha C, Burchard E, Choudhry S, Zaroff J, Lawton MT, Castro R, McCulloch CE, et al. 2005. Polymorphisms in transforming growth factor- $\beta$-related genes ALK1 and ENG are associated with sporadic brain arteriovenous malformations. Stroke 36: $2278-2280$.

Peacock HM, Caolo V, Jones EA. 2016. Arteriovenous malformations in hereditary haemorrhagic telangiectasia: Looking beyond ALK1-NOTCH interactions. Cardiovasc Res 109: 196-203.

Pece-Barbara N, Vera S, Kathirkamathamby K, Liebner S, Di Guglielmo GM, Dejana E, Wrana JL, Letarte M. 2005. Endoglin null endothelial cells proliferate faster and are more responsive to transforming growth factor- $\beta 1$ with higher affinity receptors and an activated Alk1 pathway. $J$ Biol Chem 280: 27800-27808.

Pi X, Schmitt CE, Xie L, Portbury AL, Wu Y, Lockyer P, Dyer LA, Moser M, Bu G, Flynn EJIII, et al. 2012. LRP1-dependent endocytic mechanism governs the signaling output of the bmp system in endothelial cells and in angiogenesis. Circ Res 111: 564-574.

Post S, Smits AM, van den Broek AJ, Sluijter JP, Hoefer IE, Janssen BJ, Snijder RJ, Mager JJ, Pasterkamp G, Mummery CL, et al. 2010. Impaired recruitment of HHT-1 mononuclear cells to the ischaemic heart is due to an altered CXCR4/CD26 balance. Cardiovasc Res 85: 494-502.

Rabinovitch M, Guignabert C, Humbert M, Nicolls MR. 2014. Inflammation and immunity in the pathogenesis of pulmonary arterial hypertension. Circ Res 115: 165-175. 
Ramirez F, Rifkin DB. 2009. Extracellular microfibrils: Contextual platforms for TGF- $\beta$ and BMP signaling. Curr Opin Cell Biol 21: 616-622.

Ranchoux B, Antigny F, Rucker-Martin C, Hautefort A, Pechoux C, Bogaard HJ, Dorfmuller P, Remy S, Lecerf F, Plante S, et al. 2015. Endothelial-to-mesenchymal transition in pulmonary hypertension. Circulation 131: 1006-1018.

Rathouska J, Jezkova K, Nemeckova I, Nachtigal P. 2015. Soluble endoglin, hypercholesterolemia and endothelial dysfunction. Atherosclerosis 243: 383-388.

Reddi AH. 2005. BMPs: From bone morphogenetic proteins to body morphogenetic proteins. Cytokine Growth Factor Rev 16: $249-250$.

Ricard N, Ciais D, Levet S, Subileau M, Mallet C, Zimmers TA, Lee SJ, Bidart M, Feige JJ, Bailly S. 2012. BMP9 and BMP10 are critical for postnatal retinal vascular remodeling. Blood 119: 6162-6171.

Risau W. 1997. Mechanisms of angiogenesis. Nature 386: 671-674.

Rocher C, Singla DK. 2013. SMAD-PI3K-Akt-mTOR pathway mediates BMP-7 polarization of monocytes into M2 macrophages. PLoS ONE 8: e84009.

Rocher C, Singla R, Singal PK, Parthasarathy S, Singla DK. 2012. Bone morphogenetic protein 7 polarizes THP-1 cells into M2 macrophages. Can J Physiol Pharmacol 90: 947-951.

Ross S, Hill CS. 2008. How the Smads regulate transcription. Int J Biochem Cell Biol 40: 383-408.

Rossi E, Smadja DM, Boscolo E, Langa C, Arevalo MA, Pericacho M, Gamella-Pozuelo L, Kauskot A, Botella LM, Gaussem P, et al. 2016. Endoglin regulates mural cell adhesion in the circulatory system. Cell Mol Life Sci 73: $1715-1739$.

Rudarakanchana N, Flanagan JA, Chen H, Upton PD, Machado R, Patel D, Trembath RC, Morrell NW. 2002. Functional analysis of bone morphogenetic protein type II receptor mutations underlying primary pulmonary hypertension. Hum Mol Genet 11: 1517-1525.

Ruiz S, Zhao H, Chandakkar P, Chatterjee PK, Papoin J, Blanc L, Metz CN, Campagne F, Marambaud P. 2016. A mouse model of hereditary hemorrhagic telangiectasia generated by transmammary-delivered immunoblocking of BMP9 and BMP10. Sci Rep 5: 37366.

Sanchez-Duffhues G, de Vinuesa AG, Lindeman JH, Mulder-Stapel A, DeRuiter MC, Van Munsteren C, Goumans MJ, Hierck BP, ten Dijke P. 2015. SLUG is expressed in endothelial cells lacking primary cilia to promote cellular calcification. Arterioscler Thromb Vasc Biol 35: 616627.

Saremba S, Nickel J, Seher A, Kotzsch A, Sebald W, Mueller TD. 2008. Type I receptor binding of bone morphogenetic protein 6 is dependent on N-glycosylation of the ligand. FEBS J 275: 172-183.

Satomi-Kobayashi S, Kinugasa M, Kobayashi R, Hatakeyama K, Kurogane Y, Ishida T, Emoto N, Asada Y, Takai Y, Hirata K, et al. 2012. Osteoblast-like differentiation of cultured human coronary artery smooth muscle cells by bone morphogenetic protein endothelial cell precursorderived regulator (BMPER). J Biol Chem 287: 3033630345 .
Scharpfenecker M, van Dinther M, Liu Z, van Bezooijen RL, Zhao Q, Pukac L, Lowik CW, ten Dijke P. 2007. BMP-9 signals via ALK1 and inhibits bFGF-induced endothelial cell proliferation and VEGF-stimulated angiogenesis. $J$ Cell Sci 120: 964-972.

Seghers L, de Vries MR, Pardali E, Hoefer IE, Hierck BP, ten Dijke P, Goumans MJ, Quax PH. 2012. Shear induced collateral artery growth modulated by endoglin but not by ALK1. J Cell Mol Med 16: 2440-2450.

Seki T, Yun J, Oh SP. 2003. Arterial endothelium-specific activin receptor-like kinase 1 expression suggests its role in arterialization and vascular remodeling. Circ Res 93: $682-689$.

Sengle G, Ono RN, Lyons KM, Bachinger HP, Sakai LY. 2008. A new model for growth factor activation: Type II receptors compete with the prodomain for BMP-7. J Mol Biol 381: 1025-1039.

Sengle G, Ono RN, Sasaki T, Sakai LY. 2011. Prodomains of transforming growth factor- $\beta$ (TGF- $\beta$ ) superfamily members specify different functions: Extracellular matrix interactions and growth factor bioavailability. J Biol Chem 286: 5087-5099.

Shapiro S, Traiger GL, Turner M, McGoon MD, Wason P, Barst RJ. 2012. Sex differences in the diagnosis, treatment, and outcome of patients with pulmonary arterial hypertension enrolled in the registry to evaluate early and longterm pulmonary arterial hypertension disease management. Chest 141: 363-373.

Shibuya H, Iwata H, Masuyama N, Gotoh Y, Yamaguchi K, Irie K, Matsumoto K, Nishida E, Ueno N. 1998. Role of TAK1 and TAB1 in BMP signaling in early Xenopus development. EMBO J 17: 1019-1028.

Shim JH, Greenblatt MB, Xie M, Schneider MD, Zou W, Zhai B, Gygi S, Glimcher LH. 2009. TAK1 is an essential regulator of BMP signalling in cartilage. $E M B O J$ 28: 2028-2041.

Shore EM, Xu M, Feldman GJ, Fenstermacher DA, Cho TJ, Choi IH, Connor JM, Delai P, Glaser DL, LeMerrer M, et al. 2006. A recurrent mutation in the BMP type I receptor ACVR1 causes inherited and sporadic fibrodysplasia ossificans progressiva. Nat Genet 38: 525-527.

Shovlin CL. 2010. Hereditary haemorrhagic telangiectasia: Pathophysiology, diagnosis and treatment. Blood Rev 24: 203-219.

Sieber C, Kopf J, Hiepen C, Knaus P. 2009. Recent advances in BMP receptor signaling. Cytokine Growth Factor Rev 20: $343-355$.

Simoes Sato AY, Bub GL, Campos AH. 2014. BMP-2 and -4 produced by vascular smooth muscle cells from atherosclerotic lesions induce monocyte chemotaxis through direct BMPRII activation. Atherosclerosis 235: 45-55.

Simonneau G, Gatzoulis MA, Adatia I, Celermajer D, Denton C, Ghofrani A, Gomez Sanchez MA, Krishna Kumar R, Landzberg M, Machado RF, et al. 2013. Updated clinical classification of pulmonary hypertension. J Am Coll Cardiol 62: D34-D41.

Singla DK, Singla R, Wang J. 2016. BMP-7 treatment increases M2 macrophage differentiation and reduces inflammation and plaque formation in Apo $\mathrm{E}^{-/-}$mice. PLOS ONE 11: e0147897.

Song Y, Jones JE, Beppu H, Keaney JFJr, Loscalzo J, Zhang YY. 2005. Increased susceptibility to pulmonary hyper- 


\section{M.-J. Goumans et al.}

tension in heterozygous BMPR2-mutant mice. Circulation 112: 553-562.

Song K, Krause C, Shi S, Patterson M, Suto R, Grgurevic L, Vukicevic S, van Dinther M, Falb D, ten Dijke P, et al. 2010. Identification of a key residue mediating bone morphogenetic protein (BMP)-6 resistance to noggin inhibition allows for engineered BMPs with superior agonist activity. J Biol Chem 285: 12169-12180.

Song R, Fullerton DA, Ao L, Zheng D, Zhao KS, Meng X. 2015. BMP-2 and TGF- $\beta 1$ mediate biglycan-induced pro-osteogenic reprogramming in aortic valve interstitial cells. J Mol Med (Berl) 93: 403-412.

Soon E, Crosby A, Southwood M, Yang P, Tajsic T, Toshner M, Appleby S, Shanahan CM, Bloch KD, Pepke-Zaba J, et al. 2015. Bone morphogenetic protein receptor type II deficiency and increased inflammatory cytokine production. A gateway to pulmonary arterial hypertension. Am J Respir Crit Care Med 192: 859-872.

Souza TA, Chen X, Guo Y, Sava P, Zhang J, Hill JJ, Yaworsky PJ, Qiu Y. 2008. Proteomic identification and functional validation of activins and bone morphogenetic protein 11 as candidate novel muscle mass regulators. Mol Endocrinol 22: 2689-2702.

Spiekerkoetter E, Tian X, Cai J, Hopper RK, Sudheendra D, Li CG, El-Bizri N, Sawada H, Haghighat R, Chan R, et al. 2013. FK506 activates BMPR2, rescues endothelial dysfunction, and reverses pulmonary hypertension. J Clin Invest 123: 3600-3613.

Spiekerkoetter E, Sung YK, Sudheendra D, Bill M, Aldred MA, van de Veerdonk MC, Vonk Noordegraaf A, Long Boyle J, Dash R, Yang PC, et al. 2015. Low-dose FK506 (tacrolimus) in end-stage pulmonary arterial hypertension. Am J Respir Crit Care Med 192: 254-257.

Srinivasan S, Hanes MA, Dickens T, Porteous ME, Oh SP Hale LP, Marchuk DA. 2003. A mouse model for hereditary hemorrhagic telangiectasia (HHT) type 2. Hum Mol Genet 12: 473-482.

Srinivasan RS, Escobedo N, Yang Y, Interiano A, Dillard ME, Finkelstein D, Mukatira S, Gil HJ, Nurmi H, Alitalo K, et al. 2014. The Prox1-Vegfr3 feedback loop maintains the identity and the number of lymphatic endothelial cell progenitors. Genes Dev 28: 2175-2187.

Stahl S, Gaetzner S, Voss K, Brackertz B, Schleider E, Surucu O, Kunze E, Netzer C, Korenke C, Finckh U, et al. 2008. Novel CCM1, CCM2, and CCM3 mutations in patients with cerebral cavernous malformations: In-frame deletion in CCM2 prevents formation of a CCM1/CCM2/ CCM3 protein complex. Hum Mutat 29: 709-717.

Strasky Z, Vecerova L, Rathouska J, Slanarova M, Brcakova E, Kudlackova Z, Andrys C, Micuda S, Nachtigal P. 2011. Cholesterol effects on endoglin and its downstream pathways in ApoE/LDLR double knockout mice. Circ J 75: 1747-1755.

Suzuki Y, Ohga N, Morishita Y, Hida K, Miyazono K, Watabe T. 2010. BMP-9 induces proliferation of multiple types of endothelial cells in vitro and in vivo. J Cell Sci 123: $1684-$ 1692.

Takahashi H, Goto N, Kojima Y, Tsuda Y, Morio Y, Muramatsu M, Fukuchi Y. 2006. Downregulation of type II bone morphogenetic protein receptor in hypoxic pulmonary hypertension. Am J Physiol Lung Cell Mol Physiol 290: L450-L458.
Talati M, West J, Zaynagetdinov R, Hong CC, Han W, Blackwell T, Robinson L, Blackwell TS, Lane K. 2014. BMP pathway regulation of and by macrophages. PLOS ONE 9: e94119.

ten Dijke P, Goumans MJ, Pardali E. 2008. Endoglin in angiogenesis and vascular diseases. Angiogenesis 11: 79-89.

Tian F, Zhou AX, Smits AM, Larsson E, Goumans MJ, Heldin CH, Boren J, Akyurek LM. 2010. Endothelial cells are activated during hypoxia via endoglin/ALK-1/SMAD1/ 5 signaling in vivo and in vitro. Biochem Biophys Res Commun 392: 283-288.

Tian H, Mythreye K, Golzio C, Katsanis N, Blobe GC. 2012. Endoglin mediates fibronectin/ $\alpha 5 \beta 1$ integrin and TGF$\beta$ pathway crosstalk in endothelial cells. EMBO J 31: 3885-3900.

Tillet E, Bailly S. 2014. Emerging roles of BMP9 and BMP10 in hereditary hemorrhagic telangiectasia. Front Genet 5: 456.

Tkachenko E, Gutierrez E, Saikin SK, Fogelstrand P, Kim C, Groisman A, Ginsberg MH. 2013. The nucleus of endothelial cell as a sensor of blood flow direction. Biology Open 2: 1007-1012.

Toporsian M, Jerkic M, Zhou YQ, Kabir MG, Yu LX, McIntyre BA, Davis A, Wang YJ, Stewart DJ, Belik J, et al. 2010. Spontaneous adult-onset pulmonary arterial hypertension attributable to increased endothelial oxidative stress in a murine model of hereditary hemorrhagic telangiectasia. Arterioscler Thromb Vasc Biol 30: 509-517.

Topper JN, Cai J, Qiu Y, Anderson KR, Xu YY, Deeds JD, Feeley R, Gimeno CJ, Woolf EA, Tayber O, et al. 1997. Vascular MADs: Two novel MAD-related genes selectively inducible by flow in human vascular endothelium. Proc Natl Acad Sci 94: 9314-9319.

Torsney E, Charlton R, Diamond AG, Burn J, Soames JV, Arthur HM. 2003. Mouse model for hereditary hemorrhagic telangiectasia has a generalized vascular abnormality. Circulation 107: 1653-1657.

Townson SA, Martinez-Hackert E, Greppi C, Lowden P, Sako D, Liu J, Ucran JA, Liharska K, Underwood KW, Seehra J, et al. 2012. Specificity and structure of a high affinity activin receptor-like kinase 1 (ALK1) signaling complex. J Biol Chem 287: 27313-27325.

Tual-Chalot S, Mahmoud M, Allinson KR, Redgrave RE, Zhai Z, Oh SP, Fruttiger M, Arthur HM. 2014. Endothelial depletion of Acvrl1 in mice leads to arteriovenous malformations associated with reduced endoglin expression. PLoS ONE 9: e98646.

Tual-Chalot S, Oh SP, Arthur HM. 2015. Mouse models of hereditary hemorrhagic telangiectasia: Recent advances and future challenges. Front Genet 6: 25.

Tuder RM, Stacher E, Robinson J, Kumar R, Graham BB. 2013. Pathology of pulmonary hypertension. Clin Chest Med 34: 639-650.

Umulis D, O'Connor MB, Blair SS. 2009. The extracellular regulation of bone morphogenetic protein signaling. $D e-$ velopment 136: $3715-3728$.

Upton PD, Morrell NW. 2009. TGF- $\beta$ and BMPR-II pharmacology-Implications for pulmonary vascular diseases. Curr Opin Pharmacol 9: 274-280.

Upton PD, Long L, Trembath RC, Morrell NW. 2008. Functional characterization of bone morphogenetic protein 
binding sites and Smad $1 / 5$ activation in human vascular cells. Mol Pharmacol 73: 539-552.

Upton PD, Davies RJ, Trembath RC, Morrell NW. 2009. Bone morphogenetic protein (BMP) and activin type II receptors balance BMP9 signals mediated by activin receptor-like kinase-1 in human pulmonary artery endothelial cells. J Biol Chem 284: 15794-15804.

Urist MR. 1965. Bone: Formation by autoinduction. Science 150: $893-899$.

Urness LD, Sorensen LK, Li DY. 2000. Arteriovenous malformations in mice lacking activin receptor-like kinase-1. Nat Genet 26: 328-331.

Valbuena-Diez AC, Blanco FJ, Oujo B, Langa C, GonzalezNunez M, Llano E, Pendas AM, Diaz M, Castrillo A, Lopez-Novoa JM, et al. 2012. Oxysterol-induced soluble endoglin release and its involvement in hypertension. Circulation 126: 2612-2624.

Valdimarsdottir G, Goumans MJ, Itoh F, Itoh S, Heldin CH, ten Dijke P. 2006. Smad7 and protein phosphatase $1 \alpha$ are critical determinants in the duration of TGF- $\beta /$ ALK1 signaling in endothelial cells. BMC Cell Biol 7: 16.

van Laake LW, van den Driesche S, Post S, Feijen A, Jansen MA, Driessens MH, Mager JJ, Snijder RJ, Westermann CJ, Doevendans PA, et al. 2006. Endoglin has a crucial role in blood cell-mediated vascular repair. Circulation 114: 2288-2297.

Venkatesha S, Toporsian M, Lam C, Hanai J, Mammoto T, Kim YM, Bdolah Y, Lim KH, Yuan HT, Libermann TA, et al. 2006. Soluble endoglin contributes to the pathogenesis of preeclampsia. Nat Med 12: 642-649.

Vittet D. 2014. Lymphatic collecting vessel maturation and valve morphogenesis. Microvasc Res 96: 31-37.

Vukicevic S, Grgurevic L. 2009. BMP-6 and mesenchymal stem cell differentiation. Cytokine Growth Factor Rev 20: 441-448.

Wakayama Y, Fukuhara S, Ando K, Matsuda M, Mochizuki N. 2015. Cdc42 mediates Bmp-induced sprouting angiogenesis through Fmnl3-driven assembly of endothelial filopodia in zebrafish. Dev Cell 32: 109-122.

Walker EJ, Su H, Shen F, Choi EJ, Oh SP, Chen G, Lawton MT, Kim H, Chen Y, Chen W, et al. 2011. Arteriovenous malformation in the adult mouse brain resembling the human disease. Ann Neurol 69: 954-962.

Walker EJ, Su H, Shen F, Degos V, Amend G, Jun K, Young WL. 2012. Bevacizumab attenuates VEGF-induced angiogenesis and vascular malformations in the adult mouse brain. Stroke 43: 1925-1930.

Walshe TE, Dole VS, Maharaj AS, Patten IS, Wagner DD, D'Amore PA. 2009. Inhibition of VEGF or TGF- $\beta$ signaling activates endothelium and increases leukocyte rolling. Arterioscler Thromb Vasc Biol 29: 1185-1192.

Wang X, Harris RE, Bayston LJ, Ashe HL. 2008. Type IV collagens regulate BMP signalling in Drosophila. Nature 455: 72-77.

Wang G, Fan R, Ji R, Zou W, Penny DJ, Varghese NP, Fan Y. 2016a. Novel homozygous BMP9 nonsense mutation causes pulmonary arterial hypertension: A case report. BMC Pulm Med 16: 17.

Wang X, Solban N, Khanna P, Callea M, Song J, Alsop DC, Pearsall RS, Atkins MB, Mier JW, Signoretti S, et al. 2016b. Inhibition of ALK1 signaling with dalantercept combined with VEGFR TKI leads to tumor stasis in renal cell carcinoma. Oncotarget 7: 41857-41869.

Weis SM, Cheresh DA. 2005. Pathophysiological consequences of VEGF-induced vascular permeability. Nature 437: 497-504.

West J, Fagan K, Steudel W, Fouty B, Lane K, Harral J, Hoedt-Miller M, Tada Y, Ozimek J, Tuder R, et al. 2004. Pulmonary hypertension in transgenic mice expressing a dominant-negative BMPRII gene in smooth muscle. Circ Res 94: 1109-1114.

West J, Harral J, Lane K, Deng Y, Ickes B, Crona D, Albu S, Stewart D, Fagan K. 2008. Mice expressing BMPR2 ${ }^{\mathrm{R} 899 \mathrm{X}}$ transgene in smooth muscle develop pulmonary vascular lesions. Am J Physiol Lung Cell Mol Physiol 295: L744L755.

Willis MS, Dyer LA, Ren R, Lockyer P, Moreno-Miralles I, Schisler JC, Patterson C. 2013. BMPER regulates cardiomyocyte size and vessel density in vivo. Cardiovasc Pathol 22: $228-240$.

Wohl AP, Troilo H, Collins RF, Baldock C, Sengle G. 2016. Extracellular regulation of bone morphogenetic protein activity by the microfibril component fibrillin-1. J Biol Chem 291: 12732-12746.

Wooderchak-Donahue WL, McDonald J, O'Fallon B, Upton PD, Li W, Roman BL, Young S, Plant P, Fulop GT, Langa C, et al. 2013. BMP9 mutations cause a vascular-anomaly syndrome with phenotypic overlap with hereditary hemorrhagic telangiectasia. Am J Hum Genet 93: 530-537.

Xu B, Wu YQ, Huey M, Arthur HM, Marchuk DA, Hashimoto T, Young WL, Yang GY. 2004. Vascular endothelial growth factor induces abnormal microvasculature in the endoglin heterozygous mouse brain. J Cereb Blood Flow Metab 24: 237-244.

* Xu P, Lin X, Feng X-H. 2016. Posttranslational regulation of Smads. Cold Spring Harb Perspect Biol 8: a022087.

Yadin D, Knaus P, Mueller TD. 2016. Structural insights into BMP receptors: Specificity, activation and inhibition. $C y-$ tokine Growth Factor Rev 27: 13-34.

Yamaguchi K, Shirakabe K, Shibuya H, Irie K, Oishi I, Ueno N, Taniguchi T, Nishida E, Matsumoto K. 1995. Identification of a member of the MAPKKK family as a potential mediator of TGF- $\beta$ signal transduction. Science 270: 2008-2011.

Yang Y, Oliver G. 2014. Development of the mammalian lymphatic vasculature. J Clin Invest 124: 888-897.

Yang X, Castilla LH, Xu X, Li C, Gotay J, Weinstein M, Liu PP, Deng CX. 1999. Angiogenesis defects and mesenchymal apoptosis in mice lacking SMAD5. Development 126: 1571-1580.

Yang Y, Garcia-Verdugo JM, Soriano-Navarro M, Srinivasan RS, Scallan JP, Singh MK, Epstein JA, Oliver G. 2012. Lymphatic endothelial progenitors bud from the cardinal vein and intersomitic vessels in mammalian embryos. Blood 120: 2340-2348.

Yao Y, Zebboudj AF, Shao E, Perez M, Boström K. 2006. Regulation of bone morphogenetic protein- 4 by matrix GLA protein in vascular endothelial cells involves activinlike kinase receptor 1. J Biol Chem 281: 33921-33930.

Yao Y, Bennett BJ, Wang X, Rosenfeld ME, Giachelli C, Lusis AJ, Boström KI. 2010. Inhibition of bone morphogenetic 


\section{M.-J. Goumans et al.}

proteins protects against atherosclerosis and vascular calcification. Circ Res 107: 485-494.

Yao Y, Jumabay M, Ly A, Radparvar M, Wang AH, Abdmaulen R, Boström KI. 2012. Crossveinless 2 regulates bone morphogenetic protein 9 in human and mouse vascular endothelium. Blood 119: 5037-5047.

Yao Y, Yao J, Radparvar M, Blazquez-Medela AM, Guihard PJ, Jumabay M, Boström KI. 2013. Reducing Jagged 1 and 2 levels prevents cerebral arteriovenous malformations in matrix Gla protein deficiency. Proc Natl Acad Sci 110: 19071-19076.

Yoshimatsu Y, Lee YG, Akatsu Y, Taguchi L, Suzuki HI, Cunha SI, Maruyama K, Suzuki Y, Yamazaki T, Katsura A, et al. 2013. Bone morphogenetic protein-9 inhibits lymphatic vessel formation via activin receptor-like kinase 1 during development and cancer progression. Proc Natl Acad Sci 110: 18940-18945.

Yung LM, Sanchez-Duffhues G, ten Dijke P, Yu PB. 2015. Bone morphogenetic protein 6 and oxidized low-density lipoprotein synergistically recruit osteogenic differentiation in endothelial cells. Cardiovasc Res 108: 278-287.
Zebboudj AF, Imura M, Bostrom K. 2002. Matrix GLA protein, a regulatory protein for bone morphogenetic protein-2. J Biol Chem 277: 4388-4394.

Zeng Y, Liu H, Kang K, Wang Z, Hui G, Zhang X, Zhong J, Peng W, Ramchandran R, Raj JU, et al. 2015. Hypoxia inducible factor-1 mediates expression of miR-322: Potential role in proliferation and migration of pulmonary arterial smooth muscle cells. Sci Rep 5: 12098.

* Zhang YE. 2017. Non-Smad signaling pathways of the TGF$\beta$ family. Cold Spring Harb Perspect Biol 9: a022129.

Zhang M, Sara JD, Wang FL, Liu LP, Su LX, Zhe J, Wu X, Liu JH. 2015. Increased plasma BMP-2 levels are associated with atherosclerosis burden and coronary calcification in type 2 diabetic patients. Cardiovasc Diabetol 14: 64 .

Zheng W, Aspelund A, Alitalo K. 2014. Lymphangiogenic factors, mechanisms, and applications. J Clin Invest 124: 878-887.

Zhu D, Mackenzie NC, Shanahan CM, Shroff RC, Farquharson C, MacRae VE. 2015. BMP-9 regulates the osteoblastic differentiation and calcification of vascular smooth muscle cells through an ALK1 mediated pathway. J Cell Mol Med 19: 165-174. 


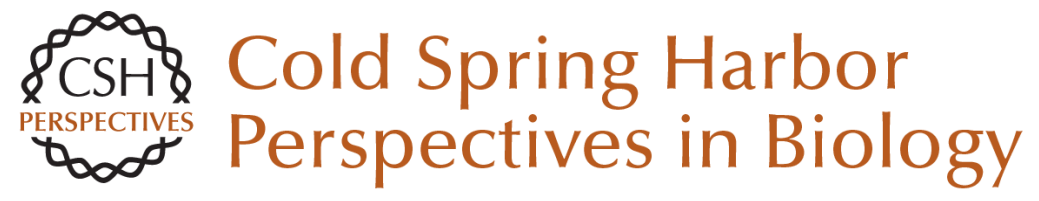

\section{Bone Morphogenetic Proteins in Vascular Homeostasis and Disease}

Marie-José Goumans, An Zwijsen, Peter ten Dijke and Sabine Bailly

Cold Spring Harb Perspect Biol 2018; doi: 10.1101/cshperspect.a031989 originally published online March 27, 2017

Subject Collection The Biology of the TGF-\&\#946; Family

TGF- $\beta$ Family Signaling in Early Vertebrate Development Joseph Zinski, Benjamin Tajer and Mary C. Mullins

Bone Morphogenetic Protein-Based Therapeutic Approaches Jonathan W. Lowery and Vicki Rosen

TGF- $\beta$ Family Signaling in Ductal Differentiation and Branching Morphogenesis Kaoru Kahata, Varun Maturi and Aristidis Moustakas

TGF- $\beta$ Signaling in Control of Cardiovascular Function Marie-José Goumans and Peter ten Dijke

TGF- $\beta$ Family Signaling in Tumor Suppression and Cancer Progression Joan Seoane and Roger R. Gomis

Targeting TGF- $\beta$ Signaling for Therapeutic Gain Rosemary J. Akhurst

Regulation of Hematopoiesis and Hematological Disease by TGF- $\beta$ Family Signaling Molecules Kazuhito Naka and Atsushi Hirao
TGF- $\beta$ Family Signaling in Mesenchymal Differentiation Ingo Grafe, Stefanie Alexander, Jonathan $R$. Peterson, et al.

TGF- $\beta 1$ Signaling and Tissue Fibrosis Kevin K. Kim, Dean Sheppard and Harold A. Chapman

Bone Morphogenetic Proteins in Vascular Homeostasis and Disease Marie-José Goumans, An Zwijsen, Peter ten Dijke, et al.

TGF- $\beta$ Family Signaling in Epithelial Differentiation and Epithelial-Mesenchymal Transition Kaoru Kahata, Mahsa Shahidi Dadras and Aristidis Moustakas

TGF- $\beta$ Family Signaling in Connective Tissue and Skeletal Diseases

Elena Gallo MacFarlane, Julia Haupt, Harry C. Dietz, et al.

The TGF- $\beta$ Family in the Reproductive Tract Diana Monsivais, Martin M. Matzuk and Stephanie A. Pangas

TGF- $\beta$ Family Signaling in Drosophila Ambuj Upadhyay, Lindsay Moss-Taylor, Myung-Jun Kim, et al.

For additional articles in this collection, see http://cshperspectives.cshlp.org/cgi/collection/

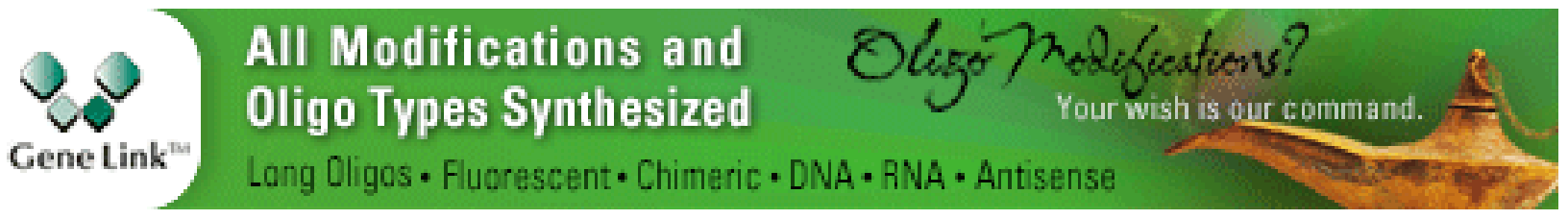


TGF- $\beta$ Family Signaling in Neural and Neuronal Differentiation, Development, and Function Emily A. Meyers and John A. Kessler
Signaling Cross Talk between TGF- $\beta /$ Smad and Other Signaling Pathways Kunxin LuO

For additional articles in this collection, see http://cshperspectives.cshlp.org/cgi/collection/

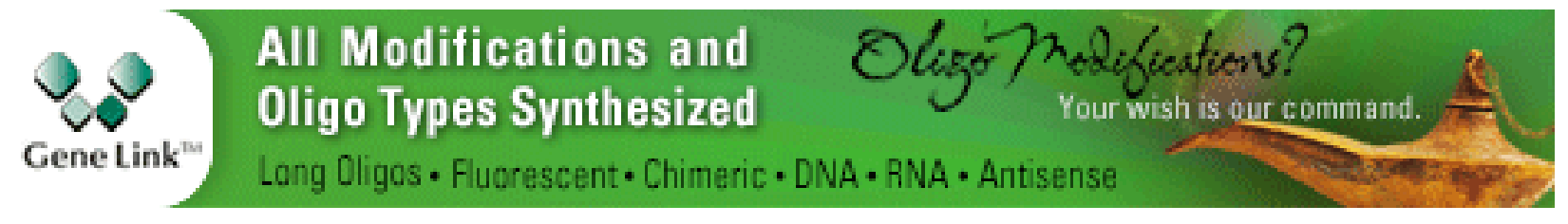

Copyright @ 2018 Cold Spring Harbor Laboratory Press; all rights reserved 